\title{
Route exploration and synthesis of the reported pyridone-based PDI inhibitor STK076545
}

\author{
Eric Greve, Sergey V Lindeman, and Chris Dockendorff* \\ Department of Chemistry, Marquette University, P.O. Box 1881, Milwaukee, WI, 53201-1881, USA
}

KEYWORDS: PDI, STK076545, aldol, $\beta$-keto-amide, pyridone, retro-Claisen

\begin{abstract}
The enzyme protein disulfide isomerase (PDI) is essential for the correct folding of proteins and the activation of certain cell surface receptors, and is a promising target for the treatment of cancer and thrombotic conditions. A previous highthroughput screen identified the commercial compound STK076545 as a promising PDI inhibitor. To confirm its activity and support further biological studies, a resynthesis was pursued of the reported $\beta$-keto-amide with an $\mathrm{N}$-alkylated pyridone at the $\alpha$-position. Numerous conventional approaches were complicated by undesired fragmentations or rearrangements. However, a successful 5-step synthetic route was achieved using an aldol reaction with an $\alpha$-pyridone allyl ester as a key step. An X-ray crystal structure of the final compound confirmed that the reported structure of STK076545 was achieved, however its lack of PDI activity and inconsistent spectral data suggest that the commercial structure was misassigned.
\end{abstract}

\section{INTRODUCTION}

Protein disulfide isomerase (PDI) is an enzyme primarily localized in the endoplasmic reticulum that catalyzes the oxidation-reduction and isomerization of disulfide bonds and serves as a necessary chaperone for protein folding. ${ }^{1}$ In addition, PDI can be released onto the surface of endothelial and platelet cells, where they act to promote effective coagulation via mechanisms presently under study. For these reasons, PDI inhibitors are of significant interest both for the treatment of cancer ${ }^{2}$ and the prevention of thrombosis. ${ }^{3}$ Several animal models of thrombosis have demonstrated that targeting cell surface PDI with antibodies or small molecules blocks both platelet accumulation and fibrin generation. ${ }^{4-8}$ Previously reported PDI antagonists suffer from poor selectivity, irreversibility, and/or low potency. In an effort to identify novel inhibitors of PDI with more suitable therapeutic properties, a high-throughput screen was performed by Flaumenhaft and co-workers on approximately 5,000 bioactive small molecules. ${ }^{6}$ They identified a class of flavonoids called quercertins, found in high abundance in various fruits and vegetables, that inhibit PDI. From this class, isoquercertin was found to decrease D-dimer plasma concentrations, a biomarker for venous thromboembolic disease, by a median of $22 \%$ in a phase II clinical trial. ${ }^{9}$ However, the high dose and highly variable patients responses are drawbacks of isoquercertin.

To seek additional PDI inhibitors, a second high-throughput screen was performed on 348,505 compounds from the Molecular Libraries Small Molecule Repository. ${ }^{10}$ Two series of PDI inhibitors, represented by bepristats 1a and 2a (Figure 1) were found to bind to the hydrophobic pocket of the b' domain. ${ }^{8} \mathrm{~A}$ commercial compound called STK076545 was also identified from the high-throughput screen to be a reasonably potent hit for the inhibition of PDI, and had an attractive structure for medicinal chemistry studies relative to other hits. The commercial supply of STK076545 was soon depleted, and we were unable to secure additional quantities, so we immediately endeavored to synthesize it. Its structure proved to be deceptively simple, and this manuscript describes several pitfalls that were encountered prior to its successful synthesis.

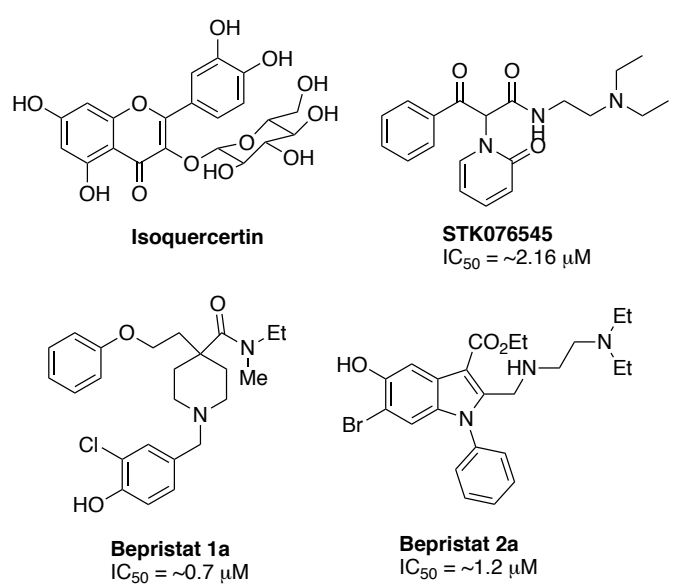

Figure 1. Select inhibitors of PDI

Methods for preparing $\beta$-keto amides have been pursued for at least a century. ${ }^{11}$ The most obvious approach to $\beta$-keto amides is via amide couplings between $\beta$-keto acids and amines, which also permits late stage diversification for medicinal chemistry studies (Figure 2, approach 'a'). However, this approach may be complicated by the limited stability of the $\beta$-keto acid starting materials, which can undergo decarboxylation (step 'c'). Alternatively, Meldrum's acid can be C-acylated, then aminolysis affords a $\beta$-keto amide, but limited to $\alpha$-unsubstituted substrates. ${ }^{12}$ Direct aminolysis of $\beta$-keto esters ${ }^{13}$ or $\beta$-keto thioesters ${ }^{14}$ at high temperature is possible (approach ' $d$ '), but can be compromised by competing enamine formation. Aminolysis reactions catalyzed with DMAP,,${ }^{15}$ enzymes, ${ }^{16}$ or transition metals ${ }^{17-18}$ have also been reported. Alternatively, addition of a ketone or enamine to an isocyanate have also been reported (approach 'e'). Cross Claisen-like condensations of esters with amide enolates have been reported (approach ' $f$ '), ${ }^{19-20}$ or alternatively an aldol reaction between a pyridone-containing amide and a benzaldehyde $(\mathrm{Ar}=\mathrm{Ph}$ for STK076545) could be envisaged (step 'g'), followed by alcohol oxidation (step ' $h$ ').

Other approaches involving a late stage addition of the pyridone are possible, but these were not initially considered since we were first interested in exploring amide structure-activity relationships (SARs), and the presence of a basic tertiary amine on the amide side chain of STK076045 could complicate a late 
stage halogenation/pyridone $\mathrm{N}$-alkylation reaction. It remained to be determined how the presence of an $\alpha$-pyridone could affect the steps outlined in Figure 2. Herein, we report our explorations of these routes, culminating in a successful 5-step synthesis of the reported structure of STK076545.

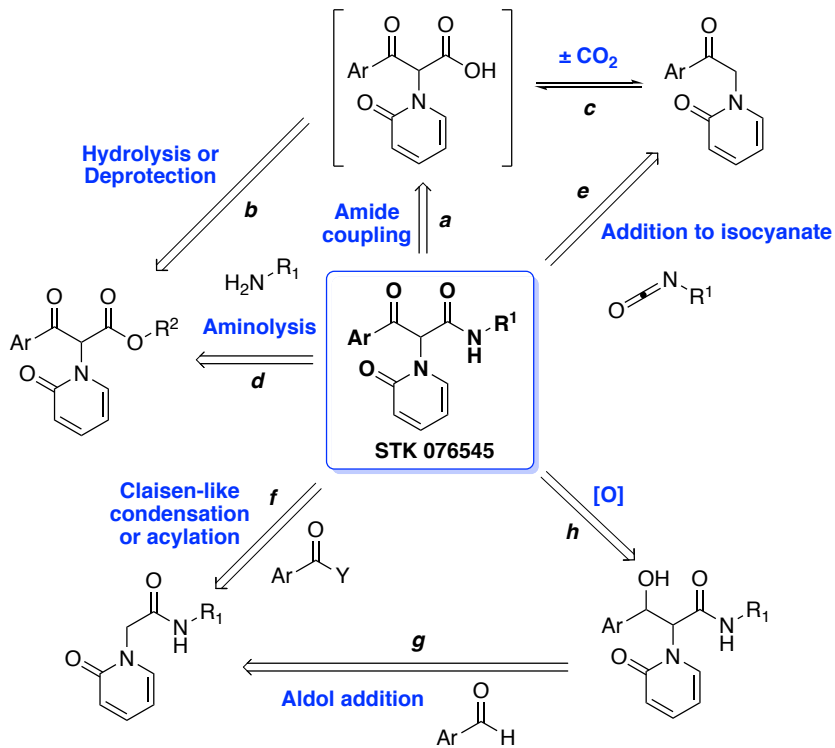

Figure 2. Retrosynthetic strategies for accessing the $\beta$-keto amide in STK076545 $\left(\mathrm{Ar}=\mathrm{Ph}, \mathrm{R}^{1}=-\mathrm{CH}_{2} \mathrm{CH}_{2} \mathrm{NEt}_{2}\right)$.

\section{RESULTS AND DISCUSSION}

Scheme 1. Ester hydrolysis and carboxylate formation

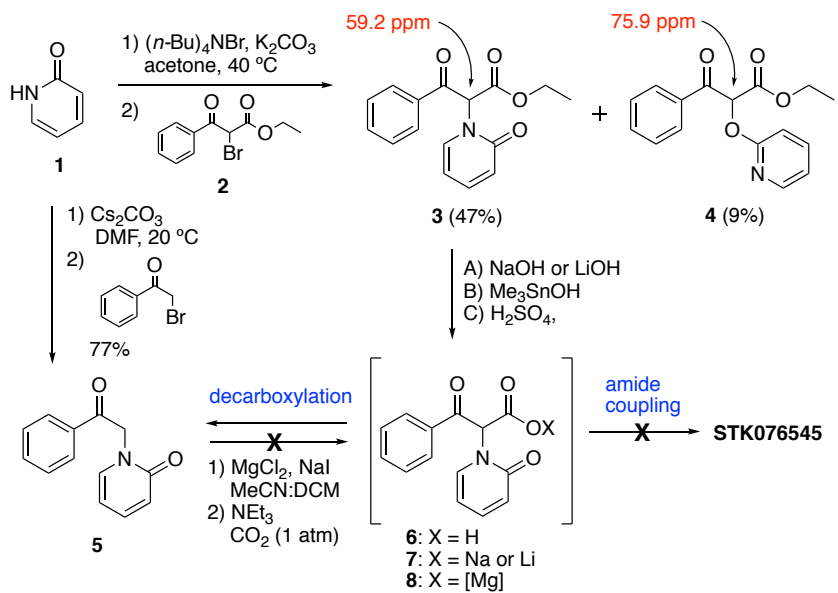

$\boldsymbol{\beta}$-Keto Carboxylic Acid. The initial synthetic route we envisioned to access STK076545 involved N-alkylation of 2-pyridone with bromo- $\beta$-keto ester $\mathbf{2}$, followed by ester hydrolysis and peptide coupling (Scheme 1). Alkylation of 2-pyridone with $\mathbf{2}$ proceeded smoothly using conditions previously reported using a bromomalonate. ${ }^{21}$ Both the $\mathrm{N}$-alkylated 3 and $\mathrm{O}$ alkylated 4 products were isolated, in $47 \%$ and $9 \%$ yield respectively. 3 and 4 were readily distinguishable based on their ${ }^{13} \mathrm{C}$ NMR chemical shifts for the $\alpha$-carbon, with the O-alkylated product 4 being assigned based on the more downfield $\alpha$-carbon peak at $75.9 \mathrm{ppm}$. In this paper, all alkylations of 2-pyridone gave $\mathrm{N}$-alkylation as the major product, though the O-alkylated products were sometimes observed in trace amounts. Unfortunately, the hydrolysis of ester 3 under acidic $\left(\mathrm{H}_{2} \mathrm{SO}_{4}\right)$ or basic conditions $\left(\mathrm{NaOH}, \mathrm{LiOH}\right.$, or $\mathrm{Me}_{3} \mathrm{SnOH}^{22}$ ) all resulted in decarboxylation of carboxylic acid intermediate $\mathbf{6}$ to yield ketone 5, despite careful attempted isolations using buffered aqueous media. Direct coupling of alkali metal carboxylate salts has been shown by Batey and coworkers to be a useful strategy with unstable carboxylic acids. ${ }^{23}$ Attempts at a tandem ester hydrolysis of 3 with $\mathrm{NaOH}$ or $\mathrm{LiOH}$ followed by peptide coupling with carboxylate 7 were not fruitful. Alternatively, the decarboxylation product 5 was synthesized on a larger scale via $\mathrm{N}$-alkylation of 2-pyridone with 2-bromoacetophenone. Subsequent carboxylation using $\mathrm{MgCl}_{2}$ and $\mathrm{NaI}$ with $\mathrm{CO}_{2}$ also gave no detectable amount of carboxylate $\mathbf{8}$ or carboxylic acid $\mathbf{6}$ after an acidic workup. $^{24}$

In an effort to access carboxylic acid $\mathbf{6}$ under milder conditions, the analogous benzyl ester intermediate 13 was synthesized in four steps (Scheme 2). First, 1,3-dicarbonyl 10 was prepared from acetophenone and dimethylcarbonate using $\mathrm{NaH}$ in 98\% yield. ${ }^{25} \mathrm{ZnO}$-catalyzed transesterification of $\mathbf{1 0}$ afforded benzyl alcohol 11. ${ }^{26}$ Next, monohalogenation of 11 with NBS catalyzed by Amberlyst- $15^{\circledR}$, followed by reaction with 2-pyridone yielded $\alpha$-substituted- $\beta$-keto ester 13 in $66 \%$ yield over two steps. ${ }^{27}$ Benzyl removal from ester 13 via palladium-catalyzed hydrogenation also resulted in decarboxylation. In addition, ${ }^{1} \mathrm{H}$ NMR analysis of the crude product indicated the ketone was reduced to afford benzyl alcohol 14. Efforts to reduce the ketone prior to ester hydrolysis were not successful (Scheme 7).

\section{Scheme 2. Synthesis and deprotection of benzyl ester 13}
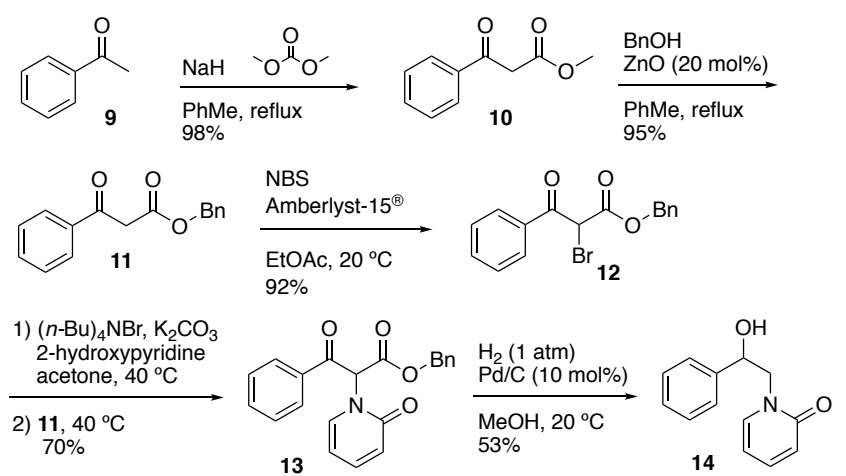

Enolate Formation and Reactivity on Ketone 5. Instead of proceeding through a carboxylic acid intermediate, we envisioned installation of the amide via reaction of an enolate with a suitable isocyanate, or CDI followed by addition of an amine to the intermediate acylimidazole. To identify suitable conditions for enolate formation with ketone 5, LDA, LiHMDS, and $\mathrm{NaH}$ were screened as bases (Table 1). Reactions were quenched at $-78^{\circ} \mathrm{C}$ or $20^{\circ} \mathrm{C}$ using $\mathrm{D}_{2} \mathrm{O}$, and crude samples were analyzed via ${ }^{1} \mathrm{H}$ NMR. Based on our screen, it was found that all reactions occurring at $20{ }^{\circ} \mathrm{C}$ facilitated enolate formation (entries 3-5), while no deuterium incorporation occurred when quenching the samples at $-78^{\circ} \mathrm{C}$ (entries 1-2). 
Table 1. Enolate formation from ketone $\mathbf{5}$

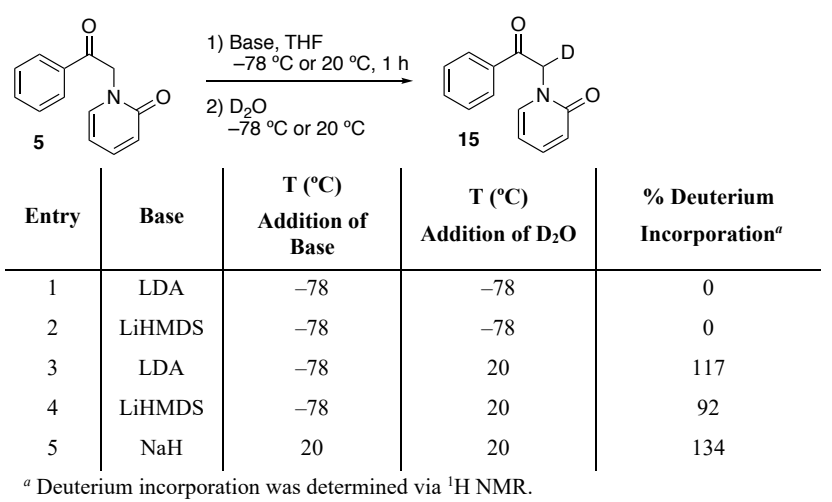

The enolate from ketone 5 was next formed using LDA at 20 ${ }^{\circ} \mathrm{C}$ and reacted with CDI or urea intermediate 16, synthesized from CDI and $N, N$-diethylethylenediamine (Scheme 3 ). There was no observable reaction with either electrophile, even after heating at $70{ }^{\circ} \mathrm{C}$. We then tested commercially available tertbutyl isocyanate as a model isocyanate for reaction screening. When LDA was used as a base, no desired product was observed. Rather, urea byproduct $\mathbf{1 8}$ formed from the addition of diisopropylamine to tert-butyl isocyanate was detected via LCMS. Switching to $\mathrm{NaH}$ as the base and heating the reaction at $100{ }^{\circ} \mathrm{C}$ for $2 \mathrm{~h}$ in toluene yielded amide 19 in $15 \%$ yield. Efforts to synthesize the desired isocyanate from $N, N$-diethylethylenediamine and triphosgene, or reacting diethylamine with 2-bromoethyl isocyanate, were both troublesome. With this synthetic route being low yielding and having the limitation of only producing secondary amides, we chose to seek an alternative route.

Scheme 3. Enolate reactions with ketone 5

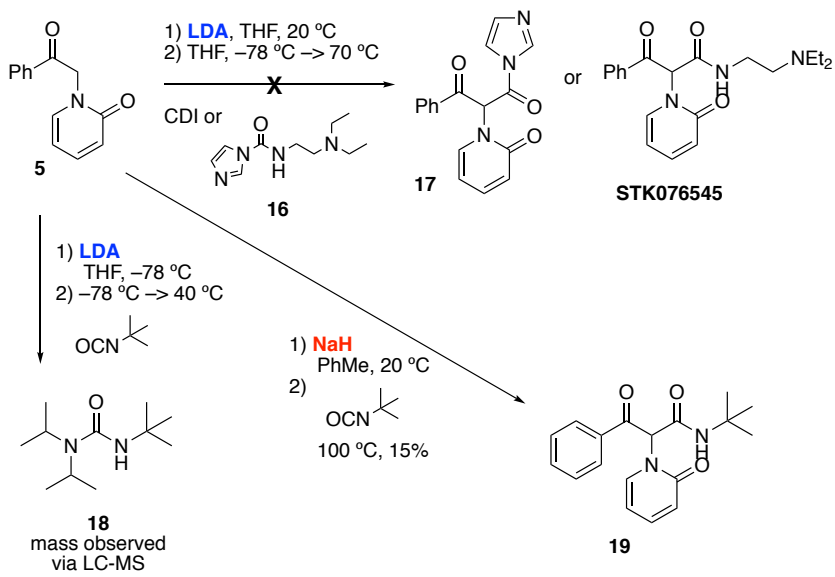

Direct Aminolysis of $\boldsymbol{\beta}$-Keto Ester. Another common synthetic approach to access amides is via direct aminolysis of esters. Starting from $\beta$-keto ester 3, we first tested a $\mathrm{Ag}(\mathrm{I})$-catalyzed aminolysis (Scheme 4). ${ }^{18}$ Rather than observing conversion to the desired $\beta$-keto amide, reaction monitoring via LCMS when using condition A showed masses associated with ester 21 and amide 24 (Scheme 5). Similarly, when heating ester 3 with $N, N$-diethyethylenediamine in toluene at $80{ }^{\circ} \mathrm{C}$ with or without DMAP, the same decomposition peaks were present. Ester 21 was isolated when using conditions B and correlated with the mass peak observed via LC-MS. Ag(I)/DBU and
DMAP were found to both accelerate the conversion to 21 in a few hours, in comparison to the reaction heated in toluene that proceeded slowly over $24 \mathrm{~h}$. We hypothesize that the $\beta$-keto ester decomposes via a retro Claisen-like condensation mechanism. The amine (or nucleophilic catalyst) could add to the ketone, followed by collapse of the tetrahedral intermediate 22 and cleavage of the $\mathrm{C}-\mathrm{C}$ bond to produce ester $\mathbf{2 1}$ (Scheme 5).

\section{Scheme 4. Direct aminolysis attempts with $\beta$-keto esters}

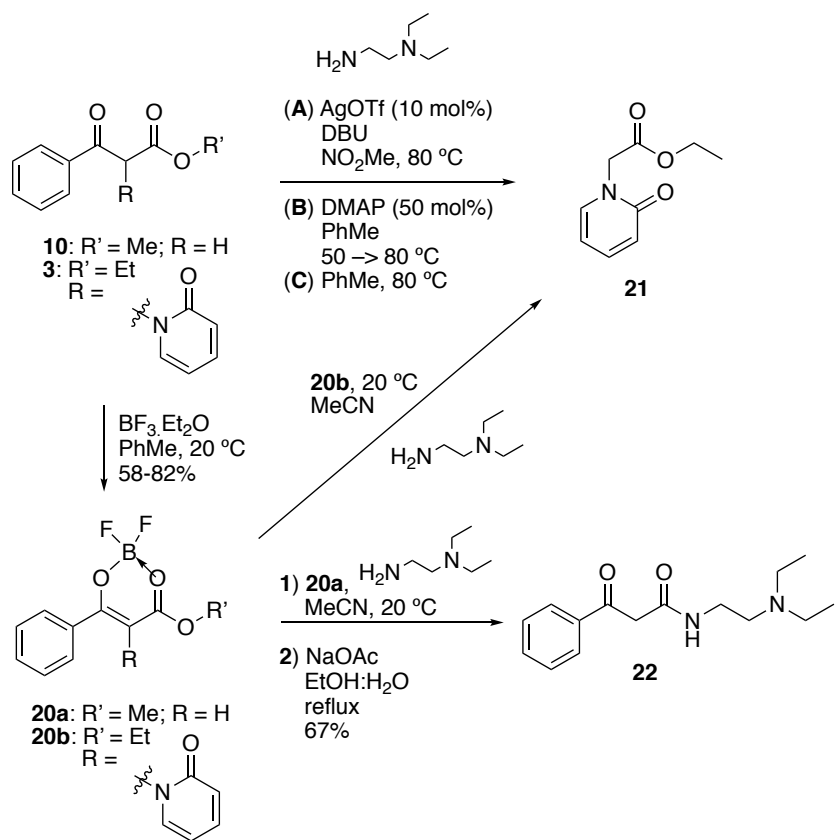

Stefane and Polanc reported a method to prepare $\beta$-keto amides from $\beta$-keto esters that proceeds via a 1,3,2-dioxaborinane intermediate. ${ }^{28}$ Reacting $\beta$-keto ester 3 with boron trifluoride etherate afforded the boron complex $\mathbf{2 0 b}$ in $82 \%$ yield (Scheme 4). Unfortunately, subsequent treatment of $\mathbf{2 0 b}$ with $N, N$-diethylethylenediamine also resulted in decomposition to ester 21 after only $1 \mathrm{~h}$, and complete decomposition after $24 \mathrm{~h}$. Interestingly, when starting from $\beta$-keto ester $\mathbf{1 0}$ which does not have the pyridone substituent in the $\alpha$ position, the preparation of the boron complex 20a and treatment with $\mathrm{N}, \mathrm{N}$-diethylethylenediamine cleanly afforded $\beta$-keto amide 22 .

Scheme 5. Proposed retro Claisen-like Condensation decomposition

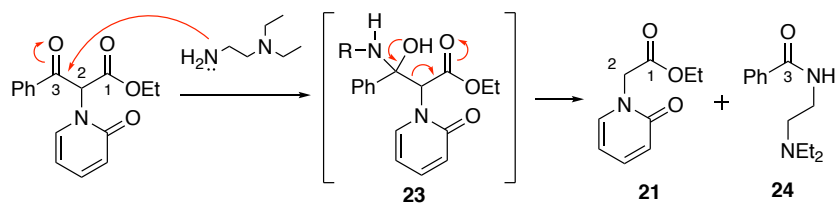

Late Stage C2-C3 Coupling Route. Inspired by our observed retro Claisen-like reaction that occurred with a $\beta$-keto ester substrate, we examined the feasibility of performing an aldol addition, Claisen-like condensation, or acylation with intermediates 27a-b (Scheme 6). Thus, installation of the C2-C3 bond would occur after amide formation and minimize the possibility of decarboxylation. Synthesis of $\mathbf{2 7} \mathbf{a}-\mathbf{b}$ began with Nalkylation of 2-pyridone with ethyl bromoacetate followed by ester hydrolysis, affording the previously reported carboxylic 
acid 25. ${ }^{29}$ Amide coupling with either $N, N$-diethylethylenediamine 25a or PMB-protected amine $\mathbf{2 6} \mathbf{b}$ yielded amides $\mathbf{2 7} \mathbf{a}-\mathbf{b}$. We prepared the PMB-protected amide $\mathbf{2 6} \mathbf{b}$ in an effort to avoid competitive deprotonation of the amide proton during enolization reactions. Extensive efforts with various electrophiles (aldehyde, ester, or acid chloride 28a-c) bases ( $\mathrm{NaOMe}, \mathrm{NaH}$, and LDA), and temperatures $\left(0-160^{\circ} \mathrm{C}\right)$ were all unfruitful.

\section{Scheme 6. C2-C3 coupling attempts on amide 26a-b}

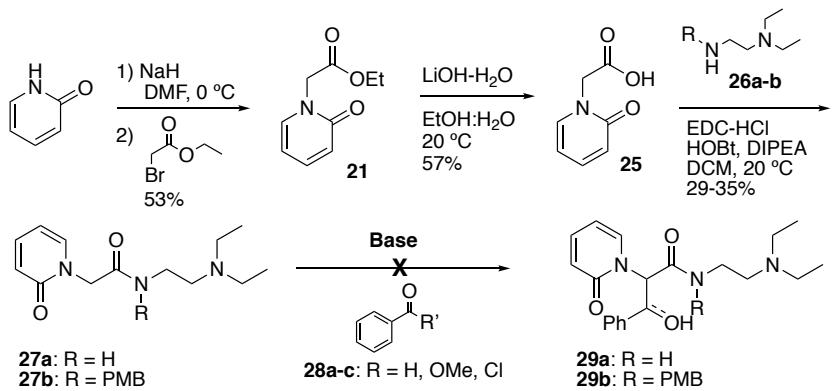

Identification of the aldol adduct as a possible intermediate provided inspiration to access alcohol 32, which would not undergo decarboxylation during ester hydrolysis (Scheme 7). Starting from benzyl esters $\mathbf{1 2}$ or $\mathbf{1 3}$, we attempted to either protect or reduce the benzylic ketone. Efforts to protect the ketone using ethylene glycol and catalytic $p$-TsOH with triethyl orthoformate and $4 \AA$ mol sieves or a Dean-Stark trap resulted in no conversion. Alternatively, an attempt to reduce the ketone with DIBAL-H resulted in pyridone reduction, as suggested by the crude ${ }^{1} \mathrm{H}$ NMR spectrum. Switching to $\mathrm{NaBH}_{4}$ produced benzyl ester 33, which we presume proceeds via a similar retroaldol reaction as observed previously.

Scheme 7. Attempted protection and reduction reactions of benzylic ketone 12 and 13<smiles>[R]C(C(=O)OBr)C(=O)c1ccccc1</smiles>

\section{$\mathrm{HOCH}_{2} \mathrm{CH}_{2} \mathrm{OH}$}

p-TsOH (10 mol\%)

A) $(\mathrm{EtO})_{3} \mathrm{CH}$

$4 \AA$ mol sieves DCE, $20 \rightarrow 50{ }^{\circ} \mathrm{C}$

B) benzene

reflux

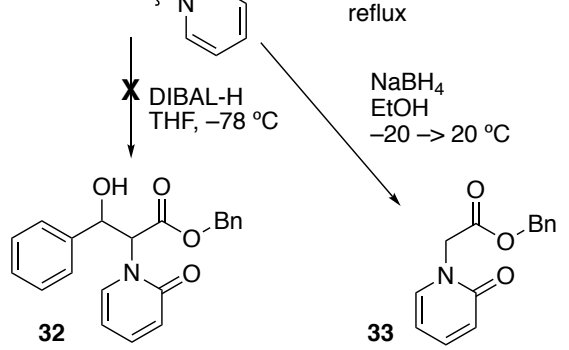

Protected Benzylic Alcohol Route. To access benzylic alcohols that could be converted to ketones late in the synthesis, we prepared bromohydrins 35a-b from the respective methyl and benzyl cinnamates using NBS and $\mathrm{I}_{2}$ as a catalyst (Scheme 8). ${ }^{30}$ This also installed alpha halides for pyridone alkylations. Under standard 2-pyridone alkylation conditions, epoxide 36 was exclusively formed. To circumvent this issue, the TBS- or MOM-protected bromohydrins 37a-b were synthesized. It was found that the use of 2,6-lutidine as base was critical, as alternative bases such as DIPEA favored epoxidation over alcohol protection. However, subjecting the TBS- or MOM-protected bromohydrin to pyridone alkylation conditions afforded only alkene $\mathbf{3 8}$ in $<20 \%$ yield. Alternatively, the acetyl-protected alcohol 39 was synthesized using acetic anhydride and catalytic DMAP. N-alkylation of 2-pyridone using 39 afforded what was initially presumed to be the desired product $\mathbf{4 0}$ and alkene $\mathbf{4 1}$ in $18 \%$ and $9 \%$ yield respectively (Scheme 9). Due to the low yields, we screened alternative solvents (acetone) and bases $\left(\mathrm{Cs}_{2} \mathrm{CO}_{3}\right)$ in an effort to increase the yield and selectivity; however, the yield of $\mathbf{4 0}$ was not improved.

\section{Scheme 8. Preparation of bromohydrin intermediates}

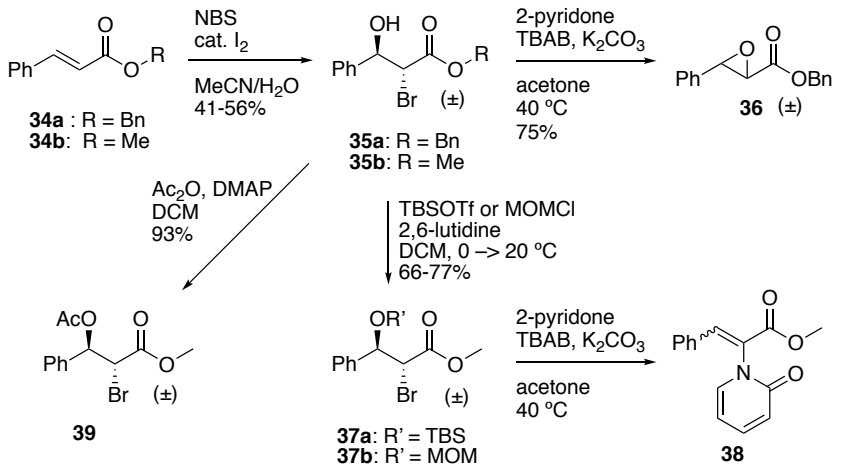

Moving forward with the synthesis, methyl ester and acetate hydrolysis proceeded smoothly to yield the presumed carboxylic acid 42a (Scheme 9). At that time, we did not suspect any issues and completed the synthetic sequence to yield 50, which was initially thought to be STK076545 (Scheme 10). N,N-diethylethylenediamine was used directly for the peptide coupling to prepare 45; however, the subsequent alcohol oxidation was unsuccessful when using DMP, PDC, IBX, or Bobbitt's salt under basic (2,6-lutidine) or acidic (silica gel) conditions. ${ }^{31}$ Instead, ethanolamine was TBS-protected to afford 44 and then used in an amide coupling using HATU with carboxylic acid $\mathbf{4 2}$ to yield 46 in $91 \%$ yield. DMP oxidation of the alcohol proceeded smoothly to afford ketone 47 , followed by TBS removal using $\mathrm{HCl}$. In a one-pot reaction, alcohol 48 underwent a mesylation followed by a substitution with diethylamine. The final product was treated with $\mathrm{HCl}$ to furnish the $\mathrm{HCl}$ salt $\mathbf{5 0}$ in $28 \%$ yield over 2 steps. 
Scheme 9. N-alkylation of 2-pyridone with acetyl-protected bromohydrin

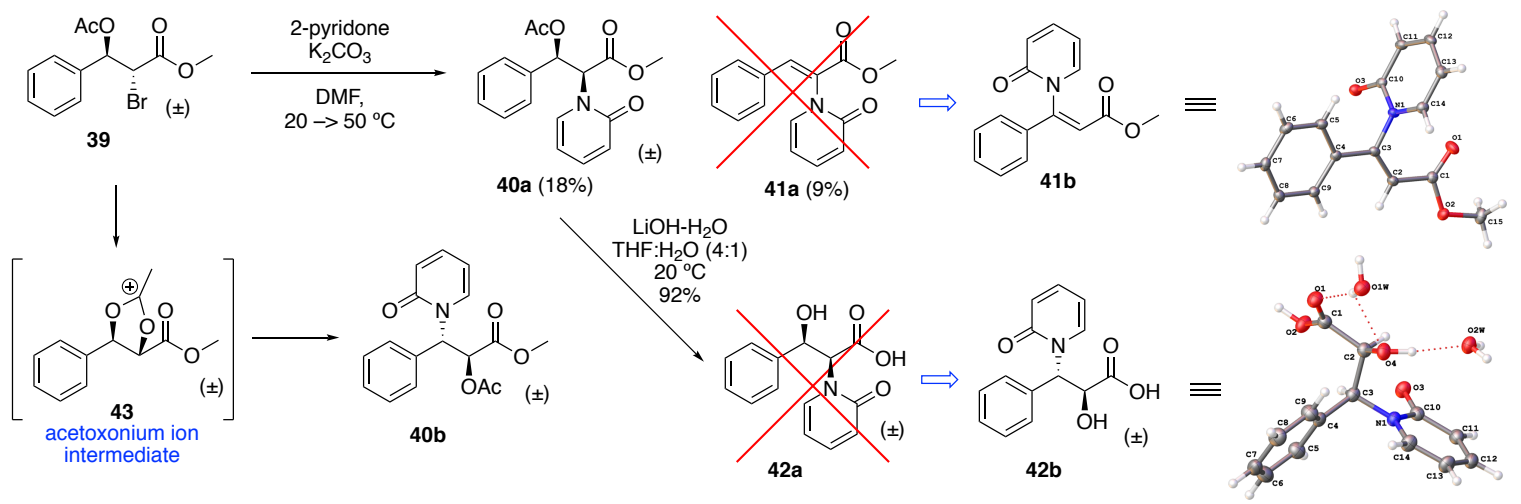

Scheme 10. Synthesis of the incorrect regioisomer of STK076545<smiles>O=C(O)C(O)C(c1ccccc1)n1ccccc1=O</smiles>

42

$$
\begin{aligned}
& \mathrm{H}_{2} \mathrm{~N} \backsim \mathrm{R}^{1} \\
& 44\left(\mathrm{R}^{1}=\mathrm{OTBS}\right) \\
& \text { HATU, DIPEA } \\
& \stackrel{\mathrm{DCE} / \mathrm{DMF}}{20^{\circ} \mathrm{C}} \\
& 91 \%
\end{aligned}
$$
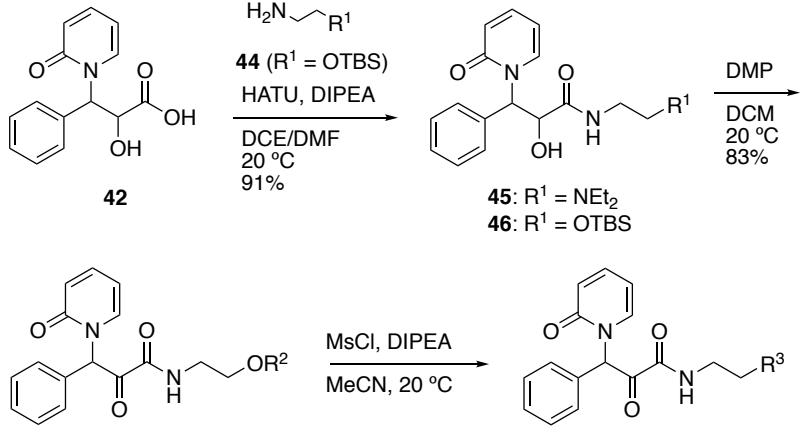

47: $\mathrm{R}^{2}=\mathrm{TBS}$
48: $\mathrm{R}^{2}=\mathrm{H}$
$\mathrm{HCl}, \mathrm{MeOH}$

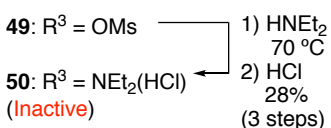

However, analogs $\mathbf{4 8}$ and $\mathbf{5 0}$ were both found to be inactive in a PDI activity assay measuring the reduction of insulin (cleavage of its disulfide bonds). Obtained X-ray crystal structures of 41b and 42b revealed that the pyridone was in the benzylic position (Scheme 9). A distinct difference between 42a and the Xray structure of $\mathbf{4 2 b}$ is the relative stereochemistry between the hydroxyl and pyridone substitutents. We propose that cyclic acetoxonium ion intermediate $\mathbf{4 3}$ is formed, similar to that proposed for the Prévost ${ }^{32}$ and Woodward ${ }^{33}$ dihydroxylation reactions, and 2-pyridone then attacks the benzylic carbon. Since we started with $(E)$-methyl cinnamate, the anti addition of water to the intermediate rac-bromonium ion results in a racemic mixture of bromohydrins 39. Formation of the proposed acetoxonium ion intermediate $\mathbf{4 3}$ and subsequent pyridone alkyation would result in inversion of both stereocenters and generate 40b. Ester hydrolysis of $\mathbf{4 0 b}$ then yielded acid $\mathbf{4 2 b}$, with its relative stereochemistry confirmed by the X-ray crystal structure (Scheme 9).

Scheme 11. Alkylation and attempted benzylic bromination

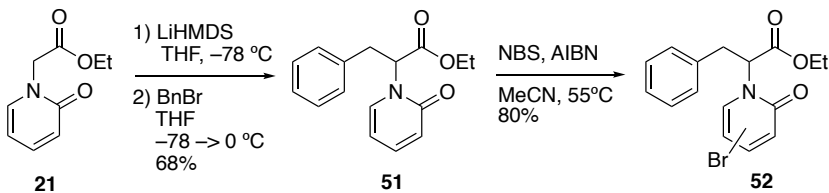

Aldol Addition Route. To circumvent the unexpected rearrangement through the acetoxonium ion intermediate, we planned to perform the $\mathrm{N}$-alkylation prior to installation of the alcohol/ketone functionality. Inspired by Easton and co-workers' use of NBS and $\mathrm{AgNO}_{3}$ to generate hydroxy- $\alpha$-amino acid derivatives, ${ }^{34}$ we sought to access a benzylic bromide intermedate from 51 (Scheme 11). Ester 21 was reacted with LiHMDS to generate an enolate, followed by alkylation with benzyl bromide to afford 51. Subsequent treatment with NBS and AIBN in MeCN yielded no bromination at the benzylic position. The $\mathrm{m} / \mathrm{z}$ peak observed in the LC-MS trace confirmed the presence of a brominated product, but the crude ${ }^{1} \mathrm{H}$ NMR spectrum suggested that bromination occurred on the pyridone. Alternatively, benzaldehyde was used instead of benzyl bromide to react with the enolate generated from ester $\mathbf{2 1}$ to access the benzylic alcohol directly (Scheme 12). Using identical conditions (LiHMDS and $0{ }^{\circ} \mathrm{C}$ ), the elimination product 53 was generated. Hydrolysis of ester $\mathbf{5 3}$ yielded carboxylic acid 54, which X-ray crystallography confirmed to be the alkene to be the $Z$ alkene.

Scheme 12. Aldol reactions with $\alpha$-pyridone ester 21
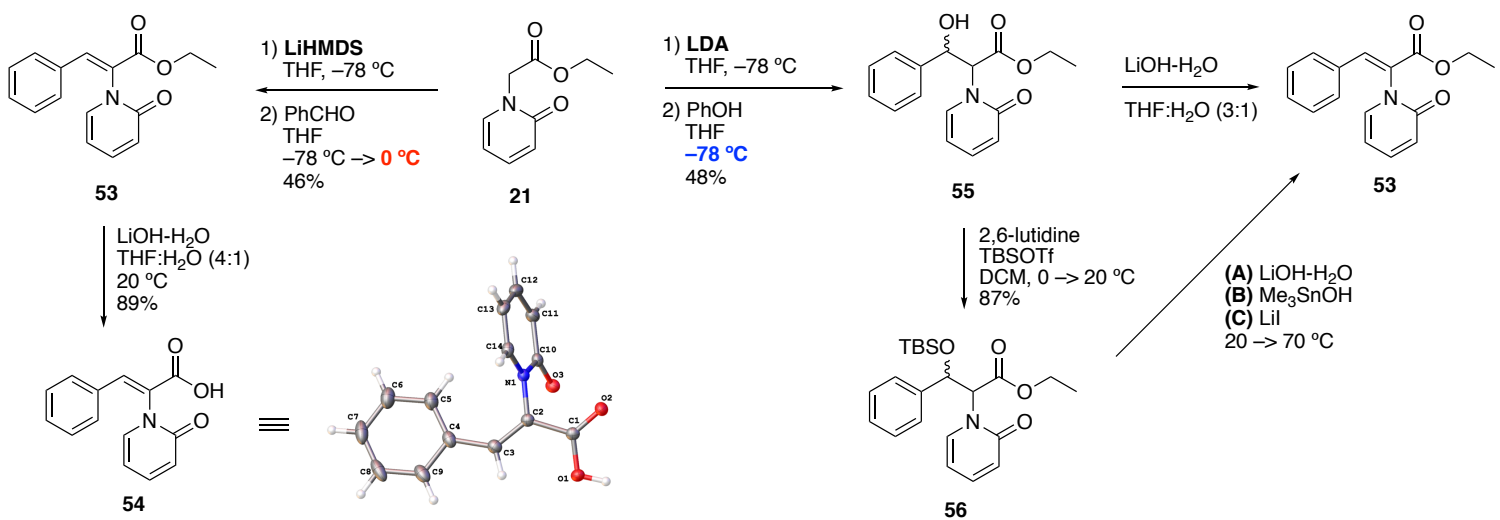
With LDA being more commonly used in the literature for aldol addition reactions with esters, we switched our base to LDA (Scheme 12). Quenching the reaction at $-78^{\circ} \mathrm{C}$ was found to be critical to avoid generation of the elimination product and give the desired alcohol 55. Unfortunately, ester hydrolysis with $\mathrm{LiOH}$ yielded the elimination product $\mathbf{5 3}$ again. In an effort to avoid generation of this undesired alkene, we synthesized the TBS-protected alcohol 56. This route was unfruitful as ester hydrolysis or cleavage using $\mathrm{LiOH}, \mathrm{Me}_{3} \mathrm{SnOH}$, or LiI all resulted in the generation of 53 .

\section{Scheme 13. Successful allyl ester route to STK076545}
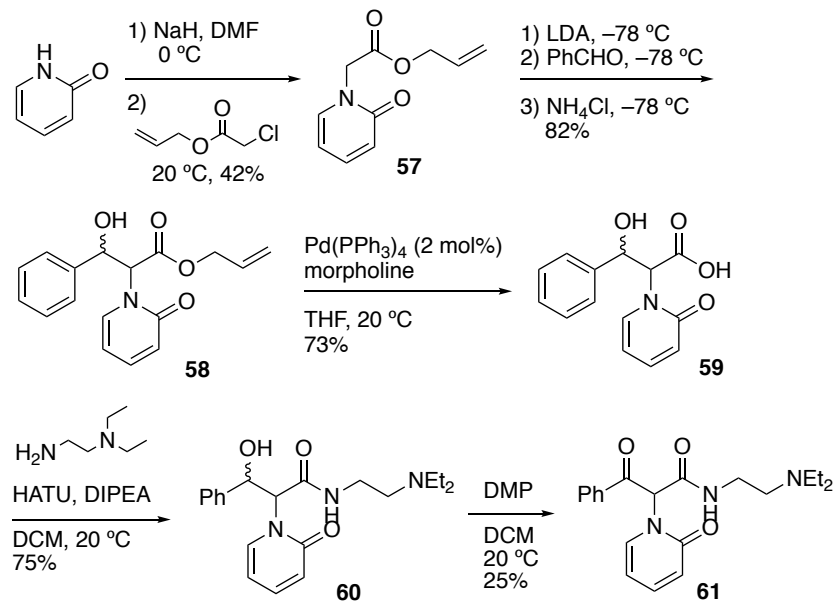

In order to access the carboxylic acid under milder conditions, we instead synthesized allyl ester 57 (Scheme 13). First, 2-pyridone was alkylated with allyl chloroacetate to yield allyl ester 57, and subsequent aldol addition using benzaldehyde afforded alcohol 58. By increasing the amount of benzaldehyde from 1 to 2 equivalents, we were able to nearly double the yield to $82 \%$ for this reaction. Allyl removal with $\mathrm{Pd}\left(\mathrm{PPh}_{3}\right)_{4}$ produced carboxylic acid 59. Amide coupling and subsequent DMP oxidation of alcohol $\mathbf{6 0}$ successfully produced the final $\beta$-keto-amide product 61 with the reported structure of STK076545. Alcohol analog 60 and the final compound $\mathbf{6 1}$ were both tested in the insulin reduction assay and found to be inactive. We obtained an X-ray crystal structure corroborating the structure of 61 (Figure 3). Interestingly, the ${ }^{1} \mathrm{H}$ and ${ }^{13} \mathrm{C}$ NMR spectra do not match that of the batch received from the commercial supplier. This confirms that the structure of the active PDI-inhibiting compound was misassigned.

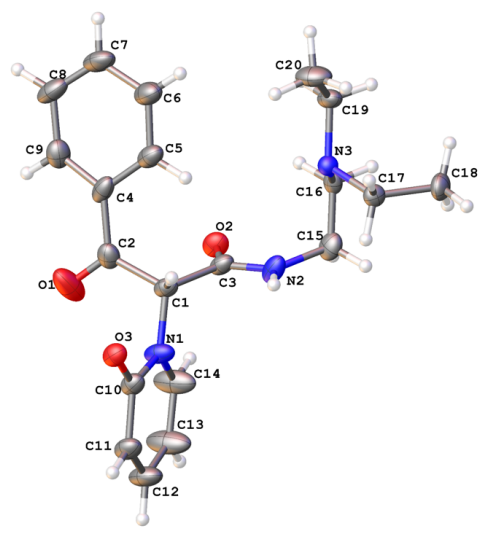

Figure 3. X-ray structure of amide 61.

\section{CONCLUSION}

Several conventional methods for forming $\beta$-keto amides resulted in fragmentation of pyridone-containing intermediates, such as retro-Claisen-like and retro-aldol reactions. Efforts to instead proceed via an acetyl protected bromohydrin resulted in a rearrangement that we propose proceeds via an acetoxonium ion intermediate. Alternatively, we successfully synthesized the reported structure of STK076545 via a 5-step synthetic route proceeding through allyl ester $\mathbf{5 8}$. This strategy should prove to be broadly useful in accessing $\beta$-keto amides, particularly with an electron-withdrawing $\alpha$-substituent such as $\mathrm{N}$-pyridone.

Unexpectedly, neither the final compound (61) nor several of its precursors were found to inhibit protein disulfide isomerase, and its ${ }^{1} \mathrm{H}$ and ${ }^{13} \mathrm{C}$ NMR spectra do not match those of the active commercial compound STK076545. It is not uncommon for complex natural products to have misassigned structures which require correction after more detailed synthetic and spectroscopic studies. ${ }^{35}$ However, it is often taken for granted that simpler commercial small molecules are provided in high purity and with structures as advertised, which is not always the case. ${ }^{36}$ Our results here highlights the importance of resynthesis and structure validation of active compounds prior to embarking on medicinal chemistry campaigns. Current efforts in our lab are ongoing to elucidate the correct structure of the commercially supplied compound that may have useful PDI inhibitory activity.

\section{EXPERIMENTAL SECTION}

\section{General information.}

All reagents and solvents were purchased from commercial vendors and used as received, except for diethylamine, which was distilled and stored over $4 \AA$ mol sieves prior to use. Reactions were performed in ventilated fume hoods with magnetic stirring and oil bath heating, unless otherwise noted. Deionized water was purified by charcoal filtration and used for reaction workups and in reactions with water. NMR spectra were recorded on Varian $300 \mathrm{MHz}$ or $400 \mathrm{MHz}$ spectrometers as indicated. Proton and carbon chemical shifts are reported in parts per million $\left(\mathrm{ppm} ; \delta\right.$ ) relative to tetramethylsilane, $\mathrm{CDCl}_{3}$, or $\mathrm{CD}_{3} \mathrm{OD}\left({ }^{1} \mathrm{H} \delta 0,{ }^{13} \mathrm{C} \delta 77.16\right.$, or ${ }^{1} \mathrm{H} \delta 3.31,{ }^{13} \mathrm{C} \delta 49.0$, respectively). NMR data are reported as follows: chemical shifts, multiplicity $(\mathrm{br}=$ broad, $\mathrm{s}=$ singlet, $\mathrm{d}=$ doublet, $\mathrm{t}=$ triplet, $\mathrm{q}=$ quartet, $\mathrm{m}=$ multiplet); coupling constant(s) in $\mathrm{Hz}$; integration. Unless otherwise indicated, NMR data were collected at $25^{\circ} \mathrm{C}$. NMR data were processed using MestReNova software. Flash chromatography was performed using Biotage SNAP cartridges filled with 40-60 $\mu \mathrm{m}$ silica gel on Biotage Isolera systems, with photodiode array UV detectors. Analytical thin layer chromatography (TLC) was performed on Agela Technologies glass plates with $0.25 \mathrm{~mm}$ silica gel with F254 indicator. Visualization was accomplished with UV light $(254 \mathrm{~nm})$ and aqueous potassium permanganate $\left(\mathrm{KMnO}_{4}\right)$ stain followed by heating, unless otherwise noted. Tandem liquid chromatography/mass spectrometry (LC-MS) was performed on a Shimadzu LCMS2020 with autosampler, photodiode array detector, and singlequadrupole MS with ESI and APCI dual ionization, using a Peak Scientific nitrogen generator. Unless otherwise noted, a standard LC-MS method was used to analyze reactions and reaction products: Phenomenex Gemini C18 column $(100 \times 4.6$ $\mathrm{mm}, 3 \mu \mathrm{m}$ particle size, $110 \mathrm{~A}$ pore size); column temperature $40{ }^{\circ} \mathrm{C} ; 5 \mu \mathrm{L}$ of sample in $\mathrm{MeOH}$ or $\mathrm{CH}_{3} \mathrm{CN}$ at a nominal concentration of $1 \mathrm{mg} / \mathrm{mL}$ was injected, and peaks were eluted with a gradient of $25-95 \% \mathrm{CH}_{3} \mathrm{CN} / \mathrm{H}_{2} \mathrm{O}$ (both with $0.1 \%$ formic acid) over 5 min., then $95 \% \mathrm{CH}_{3} \mathrm{CN} / \mathrm{H}_{2} \mathrm{O}$ for $2 \mathrm{~min}$. 


\section{Synthetic protocols.}

Ethyl 3-oxo-2-(2-oxo-1,2-dihydropyridin-1-yl)-3-phenylpropanoate (3); ethyl 3-oxo-3-phenyl-2-(pyridin-2yloxy)propanoate (4). A suspension of 2-hydroxypyridone (163 mg, $1.72 \mathrm{mmol})$, tetrabutylammonium bromide $(59.5 \mathrm{mg}$, $0.184 \mathrm{mmol})$, and potassium carbonate $(765 \mathrm{mg}, 55.3 \mathrm{mmol}) \mathrm{in}$ acetone $(6.0 \mathrm{~mL})$ was heated to $40{ }^{\circ} \mathrm{C}$ and stirred for $30 \mathrm{~min}$. Ethyl-2-bromo-3-oxo-3-phenylpropanoate $\quad(500 \mathrm{mg}, \quad 1.84$ mmol) was added and the suspension was stirred at $40^{\circ} \mathrm{C}$ for 30 min before being cooled to $20^{\circ} \mathrm{C}$. A solution of acetic acid ( 160 $\mathrm{uL}, 2.79 \mathrm{mmol})$ in water $(2.0 \mathrm{~mL})$ was added slowly, and the mixture was stirred for $15 \mathrm{~min}$. The resulting mixture was diluted with $\mathrm{H}_{2} \mathrm{O}(2.0 \mathrm{~mL})$ and extracted with DCM (3 x $\left.15 \mathrm{~mL}\right)$. The combined organic layers were dried over anhydrous $\mathrm{Na}_{2} \mathrm{SO}_{4}$, filtered, and concentrated. The crude orange oil was dissolved in DCM and purified via flash chromatography (25 g $\mathrm{SiO}_{2}$ column, 0-60\% EtOAc/hexanes) to yield pyridone 3 as a yellow oil (229 mg, 47\%) and 4 as a yellow oil (44 mg, 9\%). 3: $\mathrm{R}_{\mathrm{f}}=0.25$ (50:50 EtOAc:hexanes); ${ }^{1} \mathrm{H}$ NMR $\left(\mathrm{CDCl}_{3}, 400 \mathrm{MHz}\right)$ $\delta 8.09(\mathrm{~d}, J=7.3 \mathrm{~Hz}, 2 \mathrm{H}), 7.64-7.58(\mathrm{~m}, 2 \mathrm{H}), 7.51-7.46(\mathrm{~m}$, $3 \mathrm{H}), 7.37-7.33(\mathrm{~m}, 1 \mathrm{H}), 6.62(\mathrm{~d}, J=8.7 \mathrm{~Hz}, 1 \mathrm{H}), 6.22-6.18(\mathrm{~m}$, 1H), 4.31-4.28 (m, 2H), $1.27(\mathrm{t}, J=7.1 \mathrm{~Hz}, 3 \mathrm{H}) ;{ }^{13} \mathrm{C} \mathrm{NMR}$ $\left(\mathrm{CDCl}_{3}, 100 \mathrm{MHz}\right) \delta 191.9,166.6,161.4,140.6,136.4,134.8$, 134.0, 129.4, 129.2, 120.2, 106.4, 62.8, 59.2, 14.1; LC-MS t $\mathrm{R}_{\mathrm{R}}=$ $3.96 ; \mathrm{m} / \mathrm{z}=285.75(\mathrm{M}+\mathrm{H}) ; 4:{ }^{1} \mathrm{H}$ NMR $\left(\mathrm{CDCl}_{3}, 400 \mathrm{MHz}\right) \delta$ 8.06-7.96 (m, 3H), 7.60-7.48 (m, 5H), 6.95-6.92 (m, 1H), 4.26-4.11 (m, 2H), 1.22-1.20 (m, 3H); ${ }^{13} \mathrm{C} \mathrm{NMR}\left(\mathrm{CDCl}_{3}, 100\right.$ $\mathrm{MHz}) \delta 191.7,166.6,161.3,146.5,139.3,133.9,129.4,128.7$, $118.3,111.4,76.0,62.2,14.1 ; \mathrm{LC}-\mathrm{MS} \mathrm{t}_{\mathrm{R}}=2.86 ; \mathrm{m} / \mathrm{z}=285.75$ $(\mathrm{M}+\mathrm{H})$.

1-(2-Oxo-2-phenylethyl)-1,2-dihydropyridin-2-one (5). 2hydroxypyridine $(0.263 \mathrm{~g}, 2.76 \mathrm{mmol})$ and $\mathrm{Cs}_{2} \mathrm{CO}_{3}(1.63 \mathrm{~g}$, $5.02 \mathrm{mmol}$ ) were added to a $15 \mathrm{~mL}$ oven-dried flask with stir bar and sealed under $\mathrm{N}_{2}$. Anhydrous DMF $(5.0 \mathrm{~mL})$ was added and the suspension was stirred at $20{ }^{\circ} \mathrm{C}$ for $30 \mathrm{~min}$ before 2bromoacetophenone $(0.500 \mathrm{~g}, 2.51 \mathrm{mmol})$ was added and the suspension was stirred for an additional $1 \mathrm{~h}$ at $20^{\circ} \mathrm{C}$. A solution of glacial acetic acid $(210 \mathrm{uL}, 3.77 \mathrm{mmol})$ in $\mathrm{H}_{2} \mathrm{O}(2 \mathrm{~mL})$ was slowly added and the mixture was stirred until it turned clear and stopped bubbling ( $\sim 10 \mathrm{~min})$. The mixture was diluted with $\mathrm{H}_{2} \mathrm{O}(5 \mathrm{~mL})$ and EtOAc $(40 \mathrm{~mL})$ and the layers were separated. The organic layer was washed with water $(3 \times 15 \mathrm{~mL})$ and the combined aqueous layers were extracted with EtOAc $(10 \mathrm{~mL})$. The combined organic layers were washed with brine $(10 \mathrm{~mL})$, dried over anhydrous $\mathrm{Na}_{2} \mathrm{SO}_{4}$, filtered, and concentrated. The crude yellow solid was dissolved in DCM and purified via flash chromatography (50 g SiO 2 column, 0-100\% EtOAc/hexanes) to yield pyridone $\mathbf{5}$ as a white crystalline solid $(0.411 \mathrm{~g}, 77 \%)$. This compound has been previously reported and characterized (CAS\# 952-75-0). ${ }^{37}{ }^{1} \mathrm{H}$ NMR $\left(\mathrm{CDCl}_{3}, 400 \mathrm{MHz}\right) \delta 8.02-8.00$ $(\mathrm{m}, 2 \mathrm{H}), 7.62(\mathrm{tt}, J=7.4,1.2 \mathrm{~Hz}, 1 \mathrm{H}), 7.51-7.47(\mathrm{~m}, 1 \mathrm{H}), 7.40$ $7.35(\mathrm{~m}, 1 \mathrm{H}), 7.23-7.21(\mathrm{~m}, 1 \mathrm{H}), 6.59(\mathrm{~d}, J=9.2 \mathrm{~Hz}, 1 \mathrm{H}), 6.21$ $(\mathrm{td}, J=6.7,1.3 \mathrm{~Hz}, 1 \mathrm{H}), 2.21(\mathrm{~s}, 2 \mathrm{H}) ;{ }^{13} \mathrm{C} \mathrm{NMR}\left(\mathrm{CDCl}_{3}, 100\right.$ MHz) $\delta 192.4,162.5,140.2,138.4,134.7,134.1,129.0,128.2$, 120.8, 106.1, 54.4.

Methyl 3-oxo-3-phenylpropanoate (10). NaH (3.7 g, 60\% in mineral oil, $92 \mathrm{mmol})$ and dimethyl carbonate $(5.9 \mathrm{~g}, 66$ mmol) were added to a $250 \mathrm{~mL}$ oven-dried flask with stir bar. A reflux condenser and addition funnel were attached, the apparatus was sealed and flushed with $\mathrm{N}_{2}$, and anhydrous toluene $(33 \mathrm{~mL})$ was added under $\mathrm{N}_{2}$. After the mixture was heated to reflux, a solution of acetophenone $(3.80 \mathrm{~mL}, 32.4 \mathrm{mmol})$ in tol- uene $(17 \mathrm{~mL})$ was added dropwise over $0.5 \mathrm{~h}$. The reaction solution turned orange with the formation of a white precipitate. After the evolution of hydrogen ceased ( $\sim 15 \mathrm{~min})$, the reaction was cooled to room temperature. Glacial acetic acid $(10 \mathrm{~mL})$ was added dropwise and a heavy pasty solid separated. Ice-cold water was slowly added until the solid dissolved completely, and the reaction mixture was diluted with EtOAc $(200 \mathrm{~mL})$. The organic layer was separated, washed with $\mathrm{H}_{2} \mathrm{O}(200 \mathrm{~mL})$ and brine $(200 \mathrm{~mL})$, dried over anhydrous $\mathrm{Na}_{2} \mathrm{SO}_{4}$, filtered, and concentrated. The residue was dissolved in DCM and purified via flash chromatography (100 g $\mathrm{SiO}_{2}$ column, 0-25\% EtOAc/hexanes) to yield ester $\mathbf{1 0}$ as an orange oil (5.65 g, 98\%). This compound has been previously reported and characterized (CAS\# 614-27-7). ${ }^{1} \mathrm{H}$ NMR (300 MHz, $\left.\mathrm{CDCl}_{3}\right) \delta 12.51$ (s, 0.22 H), $7.94(\mathrm{~m}, 2 \mathrm{H}), 7.78(\mathrm{~m}, 0.44 \mathrm{H}), 7.76-7.58(\mathrm{~m}, 0.44 \mathrm{H}), 7.62-$ $7.58(\mathrm{~m}, 1 \mathrm{H}), 7.50-7.40(\mathrm{~m}, 2.7 \mathrm{H}), 5.68(\mathrm{~s}, 0.22 \mathrm{H}), 4.01(\mathrm{~s}$, 2H), 3.80 (s, $0.65 \mathrm{H}), 3.75$ (s, 3H); ${ }^{13} \mathrm{C} \mathrm{NMR}\left(75 \mathrm{MHz}, \mathrm{CDCl}_{3}\right.$ ) $\delta 192.5,173.6,171.6,168.0,136.0,133.9,133.4,131.4,128.9$, $128.64,128.6,126.2,87.1,52.6,51.5,45.8$.

Benzyl 3-oxo-3-phenylpropanoate (11). A $25 \mathrm{~mL}$ round bottom flask was charged with methyl 3-oxo-3-phenylpropanoate $(1.05 \mathrm{~g}, 5.91 \mathrm{mmol})$, benzyl alcohol $(6.10 \mathrm{~mL}, 59.1 \mathrm{mmol})$, $\mathrm{ZnO}(96.0 \mathrm{mg}, 1.18 \mathrm{mmol})$ and anhydrous toluene $(5 \mathrm{~mL})$. The flask was fitted with a short-path distillation head and heated in an oil bath set at $110^{\circ} \mathrm{C}$, distilling the methanol formed during the reaction. After $24 \mathrm{~h}, \mathrm{LC}-\mathrm{MS}$ analysis of the reaction mixture showed complete consumption of the starting material. The reaction mixture was filtered through a plug of Celite and concentrated. The crude residue was dissolved in DCM and purified via flash chromatography $\left(100 \mathrm{~g} \mathrm{SiO}_{2}\right.$ column, 0-20\% EtOAc/hexanes) to give benzyl ester $\mathbf{1 1}$ as a light orange oil (1.43 g, 95\%). This compound has been previously reported and characterized (CAS\# 63888-22-2). ${ }^{38}$ This compound exists as a mixture of tautomers in $\mathrm{CDCl}_{3}$ (10:1 keto:enol). ${ }^{1} \mathrm{H}$ NMR $(300$ $\left.\mathrm{MHz}, \mathrm{CDCl}_{3}\right) \delta 12.50$ (s, enol), 7.94 (d, $J=8.0 \mathrm{~Hz}$, enol), 7.90 $(\mathrm{d}, J=8.0 \mathrm{~Hz}, 2 \mathrm{H}), 7.77(\mathrm{~d}, J=7.9 \mathrm{~Hz}, \mathrm{enol}), 7.59$ (t, $J=7.5$ $\mathrm{Hz}, 1 \mathrm{H}), 7.48-7.28(\mathrm{~m}, 7 \mathrm{H}), 5.73$ (s, enol), 5.25 (s, enol), 5.19 $(\mathrm{s}, 2 \mathrm{H}), 4.04(\mathrm{~s}, 2 \mathrm{H}) ;{ }^{13} \mathrm{C}$ NMR $\left(75 \mathrm{MHz}, \mathrm{CDCl}_{3}\right) \delta 192.4$, $167.5,135.4,133.9,128.9,128.7,128.6,128.5,128.4,128.3$, $67.3,46.1$

Benzyl 2-bromo-3-oxo-3-phenylpropanoate (12). In a 100 $\mathrm{mL}$ flask with stir bar, ester 11 (1.00 g, $3.93 \mathrm{mmol}), N$-bromosuccinimide (0.735 g, $4.13 \mathrm{mmol})$, and Amberlyst-15 (2.89 g) in ethyl acetate $(30 \mathrm{~mL})$ were stirred at $20^{\circ} \mathrm{C}$ for $2.5 \mathrm{~h}$. After completion of the reaction, as indicated by LC-MS, the reaction mixture was filtered and washed with EtOAc $(2 \times 20 \mathrm{~mL})$. The combined organic filtrates were dried over anhydrous $\mathrm{Na}_{2} \mathrm{SO}_{4}$, and concentrated. The crude product was dissolved in DCM and purified via flash chromatography $\left(50 \mathrm{~g} \mathrm{SiO}_{2}\right.$ column, 0-20\% EtOAc/hexanes) to yield alkyl bromide $\mathbf{1 2}$ as a light yellow oil $(1.20 \mathrm{~g}, 92 \%)$. This compound has been previously reported and characterized (CAS\# 845733-96-2) ${ }^{27}{ }^{11} \mathrm{H}$ NMR (400 MHz, $\left.\mathrm{CDCl}_{3}\right) \delta 7.94-7.92(\mathrm{~m}, 2 \mathrm{H}), 7.58(\mathrm{~m}, 1 \mathrm{H}), 7.43(\mathrm{~m}, 2 \mathrm{H}), 7.30$ $7.23(\mathrm{~m}, 5 \mathrm{H}){ }^{13} \mathrm{C}$ NMR $\left(100 \mathrm{MHz}, \mathrm{CDCl}_{3}\right) \delta 188.0,165.1$, $134.6,134.3,133.3,129.2,128.9,128.6,128.6,128.4,68.8$, 46.4 .

Benzyl 3-oxo-2-(2-oxo-1,2-dihydropyridin-1-yl)-3-phenyl-propanoate (13). A suspension of 2-hydroxypyridone (212 $\mathrm{mg}, 2.23 \mathrm{mmol})$, tetrabutylammonium bromide $(65.4 \mathrm{mg}, 0.203$ $\mathrm{mmol})$, and potassium carbonate $(0.841 \mathrm{~g}, 6.09 \mathrm{mmol})$ in acetone $(4.0 \mathrm{~mL})$ was heated to $40{ }^{\circ} \mathrm{C}$ and stirred for $30 \mathrm{~min}$. Then, bromide 12 (676 $\mathrm{mg}, 2.03 \mathrm{mmol})$ in acetone $(0.5 \mathrm{~mL})$ was added. The suspension was stirred at $40{ }^{\circ} \mathrm{C}$ for $30 \mathrm{~min}$ and cooled to room temperature before a solution of acetic acid (232 
$\mathrm{uL}, 4.06 \mathrm{mmol})$ in water $(2.0 \mathrm{~mL})$ was added slowly. The resulting mixture was stirred for $15 \mathrm{~min}$ before it was diluted with $\mathrm{H}_{2} \mathrm{O}(5.0 \mathrm{~mL})$ and extracted with DCM $(3 \times 15 \mathrm{~mL})$. The combined organic layers were dried over anhydrous $\mathrm{Na}_{2} \mathrm{SO}_{4}$, filtered, and concentrated. The crude dark orange oil was dissolved in DCM and purified via flash chromatography (50 g $\mathrm{SiO}_{2}, 0-50 \%$ EtOAc/hexanes) to yield pyridone $\mathbf{1 3}$ as a colorless oil (496 mg, 70\%). ${ }^{1} \mathrm{H}$ NMR (400 MHz, $\left.\mathrm{CDCl}_{3}\right) \delta 8.07-$ $8.04(\mathrm{~m}, 2 \mathrm{H}), 7.64(\mathrm{~s}, 1 \mathrm{H}), 7.60(\mathrm{tt}, J=7.4,1.2 \mathrm{~Hz}, 1 \mathrm{H}), 7.48$ $7.44(\mathrm{~m}, 3 \mathrm{H}), 7.35-7.26(\mathrm{~m}, 6 \mathrm{H}), 6.61(\mathrm{~d}, J=9.2 \mathrm{~Hz}, 1 \mathrm{H}), 6.18$ $(\mathrm{td}, J=6.8 \mathrm{~Hz}, 1.3 \mathrm{~Hz}, 1 \mathrm{H}), 5.25(\mathrm{~s}, 2 \mathrm{H}) .{ }^{13} \mathrm{C}$ NMR $(100 \mathrm{MHz}$, $\left.\mathrm{CDCl}_{3}\right) \delta 191.7,166.5,161.4,140.7,136.4,134.8,134.6,133.9$, $129.4,129.2,128.7,128.7,128.4,120.3,106.4,68.3,59.4$; LC$\mathrm{MS} \mathrm{t}_{\mathrm{R}}=3.72 ; \mathrm{m} / \mathrm{z}=348.10(\mathrm{M}+\mathrm{H})$.

1-(2-Hydroxy-2-phenylethyl)-1,2-dihydropyridin-2-one (14). To a $15 \mathrm{~mL}$ flask with stir bar, 13 (33.5 mg, $0.096 \mathrm{mmol})$ and $\mathrm{MeOH}(3.0 \mathrm{~mL})$ were added. The flask headspace was flushed with $\mathrm{N}_{2}$ before $10 \% \mathrm{Pd} / \mathrm{C}(10.3,0.0096 \mathrm{mmol})$ was added. The flask was flushed with $\mathrm{H}_{2}$ and stirred under $\mathrm{H}_{2}$ (1 atm) at $20^{\circ} \mathrm{C}$ for $1 \mathrm{~h}$. After $1 \mathrm{~h}$, the reaction mixture was filtered through Celite, condensed under vacuum and analyzed via LCMS and ${ }^{1} \mathrm{H}$ NMR, which indicated conversion to alcohol $14 .{ }^{1} \mathrm{H}$ NMR of the crude product showed signals for alkyl protons at 4.36, 3.89, and $5.01 \mathrm{ppm}$, consistent with published data. This compound has been previously reported and characterized (CAS\# 69914-21-2). ${ }^{1} \mathrm{H}$ NMR (400 MHz, CD $\left.{ }_{3} \mathrm{OD}\right) \delta$ 7.43-7.39 $(\mathrm{m}, 2 \mathrm{H}), 7.39-7.33(\mathrm{~m}, 3 \mathrm{H}), 7.29-7.26(\mathrm{~m}, 2 \mathrm{H}), 6.56(\mathrm{~d}, J=8.5$ $\mathrm{Hz}, 1 \mathrm{H}), 6.30(\mathrm{td}, J=6.7,1.2 \mathrm{~Hz}, 1 \mathrm{H}), 5.01(\mathrm{dd}, \mathrm{J}=8.8,3.8 \mathrm{~Hz}$, $1 \mathrm{H}), 4.36(\mathrm{dd}, \mathrm{J}=13.1,3.8 \mathrm{~Hz}, 1 \mathrm{H}), 3.89(\mathrm{dd}, \mathrm{J}=13.1,8.8 \mathrm{~Hz}$, 1H). 215.75; LC-MS t $=1.68 ; \mathrm{m} / \mathrm{z}=215.75(\mathrm{M}+\mathrm{H})$.

$\mathrm{N}$-[2-(Diethylamino)ethyl]-1H-imidazole-1-carboxamide (16). 1,1-carbonyldiimidazole (205 $\mathrm{mg}, 1.26 \mathrm{mmol}$ ) was added to a $4 \mathrm{~mL}$ oven-dried vial with stir bar and sealed under $\mathrm{N}_{2}$. Anhydrous THF (1.2 mL) was added and the solution was cooled to $0{ }^{\circ} \mathrm{C}$ in an ice bath. A solution of $N, N$-diethylethylenediamine $(97.9 \mathrm{mg}, 0.842 \mathrm{mmol})$ in anhydrous DCM $(0.6 \mathrm{~mL})$ was added dropwise over $10 \mathrm{~min}$ and the solution was stirred at $20^{\circ} \mathrm{C}$ for $1.5 \mathrm{~h}$. Next, the solvent was removed via vacuum and the crude product was loaded on to Celite and purified via flash chromatography (12 g C18, $\mathrm{MeOH} / \mathrm{H}_{2} \mathrm{O}$ gradient) to yield urea 16 as a yellow oil (93.7 $\mathrm{mg}, 53 \%$ ). This compound has been previously reported (CAS\# 698388-51-1). ${ }^{1} \mathrm{H}$ NMR (300 MHz, $\left.\mathrm{CDCl}_{3}\right) \delta 8.18(\mathrm{~s}, 1 \mathrm{H}), 7.45-7.42(\mathrm{~m}, 1 \mathrm{H}), 7.09-7.07(\mathrm{~m}, 2 \mathrm{H})$, $3.46(\mathrm{t}, J=6.1 \mathrm{~Hz}, 2 \mathrm{H}), 2.66(\mathrm{t}, J=5.6 \mathrm{~Hz}, 2 \mathrm{H}), 2.61-2.51(\mathrm{~m}$, $4 \mathrm{H}), 1.06-0.97(\mathrm{~m}, 6 \mathrm{H}) ;{ }^{13} \mathrm{C}$ NMR $\left(75 \mathrm{MHz}, \mathrm{CDCl}_{3}\right) \delta 149.1$, 136.1, 130.3, 130.1, 116.1, 51.3, 46.8, 38.2, 11.8; LC-MS $\mathrm{t}_{\mathrm{R}}=$ $1.01 ; \mathrm{m} / \mathrm{z}=210.80(\mathrm{M}+\mathrm{H})$

N-Tert-butyl-3-oxo-2-(2-oxo-1,2-dihydropyridin-1-yl)-3phenyl propanamide (19). In a $4 \mathrm{~mL}$ oven-dried vial with a stir bar, $t$-butylisocyanate $(7.0 \mathrm{mg}, 0.071 \mathrm{mmol})$ and $\mathrm{NaH}(60 \%$ $\mathrm{w} / \mathrm{w}$ in mineral oil, $4.7 \mathrm{mg}, 0.118 \mathrm{mmol})$ were mixed in anhydrous toluene $(0.5 \mathrm{~mL})$ under $\mathrm{N}_{2}$ at $20^{\circ} \mathrm{C}$. Then, ketone $5(10.0$ $\mathrm{mg}, 0.047 \mathrm{mmol}$ ) was added in one portion and the mixture was heated at $100{ }^{\circ} \mathrm{C}$ for $2 \mathrm{~h}$. After $2 \mathrm{~h}$, the reaction was quenched by the addition of saturated ammonium chloride. The aqueous layer was extracted with DCM (3 x $10 \mathrm{~mL})$. The combined organic extracts were washed with brine $(10 \mathrm{~mL})$, dried over anhydrous $\mathrm{Na}_{2} \mathrm{SO}_{4}$, filtered, and condensed to a yellow residue. The crude product was purified via flash chromatography $(10 \mathrm{~g}$ $\mathrm{SiO}_{2}, 0-100 \%$ EtOAc/hexanes) to afford amide 19 as a yellow oil $(2.2 \mathrm{mg}, 15 \%)$ and recovered ketone $5(8.0 \mathrm{mg}, 80 \%) .{ }^{1} \mathrm{H}$ NMR (300 MHz, $\left.\mathrm{CDCl}_{3}\right) \delta 7.98(\mathrm{~d}, \mathrm{~J}=8.0 \mathrm{~Hz}, 2 \mathrm{H}), 7.74-7.72$ $(\mathrm{m}, 1 \mathrm{H}), 7.56-7.52(\mathrm{~m}, 1 \mathrm{H})$ 7.43-7.36 (m, 3H), $7.31(\mathrm{~s}, 1 \mathrm{H})$,
6.85 (br. s., $1 \mathrm{H}), 6.61$ (d, $J=9.0 \mathrm{~Hz}, 1 \mathrm{H}), 6.29$ (t, $J=6.8 \mathrm{~Hz}$, $1 \mathrm{H}) . \mathrm{LC}-\mathrm{MS} \mathrm{t}_{\mathrm{R}}=2.96 ; \mathrm{m} / \mathrm{z}=313.15(\mathrm{M}+\mathrm{H})$.

2,2-Difluoro-6-methoxy-4-phenyl-2H-1 $\lambda^{3}, 3,2 \lambda^{4}$-dioxaborinine (20a). To an oven-dried $20 \mathrm{~mL}$ vial, $10(0.420 \mathrm{~g}, 2.36$ $\mathrm{mmol}$ ) and a stir bar were added and the vial was purged with $\mathrm{N}_{2}$ for $10 \mathrm{~min}$. Then, anhydrous toluene $(10 \mathrm{~mL})$ and boron trifluoride etherate $(0.58 \mathrm{~mL}, 4.71 \mathrm{mmol})$ were sequentially added. The reaction mixture was stirred at $20{ }^{\circ} \mathrm{C}$ for $20 \mathrm{~h}$. The reaction mixture was then concentrated to $\sim 1 / 3$ of its volume and cooled to $-30{ }^{\circ} \mathrm{C}$ in a dry ice $\mathrm{MeOH} / \mathrm{H}_{2} \mathrm{O}$ cooling bath. The precipitated material was filtered off and washed with $5: 1$ petroleum ether/EtOAc $(5 \mathrm{~mL})$, yielding the boron complex 20a as a yellow solid (307 mg, 58\%). ${ }^{1} \mathrm{H}$ NMR (300 MHz, $\mathrm{CDCl}_{3}$ )

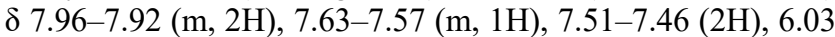
$(\mathrm{s}, 1 \mathrm{H}), 4.12(\mathrm{~s}, 3 \mathrm{H}) ;{ }^{13} \mathrm{C} \mathrm{NMR}\left(75 \mathrm{MHz}, \mathrm{CDCl}_{3}\right) \delta 179.6,176.3$, 134.0, 132.0, 129.0, 127.9, 83.2, 56.1.

Ethyl 2-(2-oxo-1,2-dihydropyridin-1-yl)acetate (21). To an oven-dried 1.0 L round bottom flask charged with a stir bar, $\mathrm{NaH}$ (60\% in mineral oil, $1.99 \mathrm{~g}, 49.9 \mathrm{mmol})$ was suspended in anhydrous DMF $(100 \mathrm{~mL})$ and cooled to $0{ }^{\circ} \mathrm{C}$ in an ice bath under $\mathrm{N}_{2}$. To the $\mathrm{NaH}$ suspension, a solution of 2-hydroxypyridine (4.07 g, $42.1 \mathrm{mmol})$ in anhydrous DMF $(200 \mathrm{~mL})$ was slowly added. The resulting solution was stirred for $1 \mathrm{~h}$ at $0{ }^{\circ} \mathrm{C}$ before ethyl bromoacetate $(4.3 \mathrm{~mL}, 38 \mathrm{mmol})$ was added and the mixture was stirred at room temperature for $1.5 \mathrm{~h}$. The reaction was quenched with saturated $\mathrm{NH}_{4} \mathrm{Cl}(40 \mathrm{~mL})$ and the product was extracted with DCM $(3 \times 150 \mathrm{~mL})$. The combined organic extracts were washed with water $(7 \times 200 \mathrm{~mL})$, dried over anhydrous $\mathrm{Na}_{2} \mathrm{SO}_{4}$, filtered, and concentrated. The crude product was dissolved in DCM and purified via flash chromatography (100 $\mathrm{g} \mathrm{SiO}_{2}, 0-100 \%$ EtOAc/hexanes) to yield ester 21 as a pale yellow oil (3.62 g, 53\%). This compound has been previously reported and characterized (CAS\# 80056-43-5). ${ }^{29} \mathrm{R}_{\mathrm{f}}$ $=0.74(\mathrm{DCM} / \mathrm{MeOH} 9: 1) .{ }^{1} \mathrm{H}$ NMR $\left(300 \mathrm{MHz}, \mathrm{CDCl}_{3}\right) \delta 1.29$ (t, 3H, J = 7.1 Hz), 4.24 (q, 2H, J = 7.1 Hz), 4.64 (s, 2H), 6.18$6.23(\mathrm{~m}, 1 \mathrm{H}), 6.58-6.61(\mathrm{~m}, 1 \mathrm{H}), 7.21-7.24(\mathrm{~m}, 1 \mathrm{H}), 7.34-7.40$ $(\mathrm{m}, 1 \mathrm{H}) .{ }^{13} \mathrm{C}$ NMR $\left(100 \mathrm{MHz}, \mathrm{CDCl}_{3}\right) \delta 14.15,50.52,61.91$, 106.22, 120.97, 121.01, 138.04, 140.27, 162.47, 167.78.

$\mathrm{N}$-[2-(Diethylamino)ethyl]-3-oxo-3-phenylpropanamide (22). $N, N$-diethylethylenediamine $(167.0 \mathrm{mg}, 1.438 \mathrm{mmol})$ was added to a $15 \mathrm{~mL}$ oven-dried flask with stir bar and sealed under $\mathrm{N}_{2}$. Anhydrous MeCN (5.0 mL) and 20a (250 mg, $\left.1.11 \mathrm{mmol}\right)$ were added, and the reaction mixture was stirred at $20^{\circ} \mathrm{C}$ for 4 h. After $4 \mathrm{~h}$, an aliquot was removed, condensed under reduced pressure, and dissolved in $\mathrm{CDCl}_{3}$ to monitor the reaction via ${ }^{1} \mathrm{H}$ NMR. The reaction mixture was condensed under vacuum, dissolved in EtOAc $(30 \mathrm{~mL})$, washed with $\mathrm{H}_{2} \mathrm{O}(2 \times 10 \mathrm{~mL})$, dried over $\mathrm{MgSO}_{4}$, filtered, and condensed under vacuum to yield complex 22 as a pale yellow oil (283 mg, 82\%). The crude oil (259 mg, $0.834 \mathrm{mmol})$, sodium acetate $(0.342 \mathrm{~g}, 4.17 \mathrm{mmol})$, ethanol $(5.0 \mathrm{~mL})$, and $\mathrm{H}_{2} \mathrm{O}(5.0 \mathrm{~mL})$ were refluxed for $8 \mathrm{~h}$. TLC analysis $(10 \% \mathrm{MeOH} / \mathrm{DCM})$ of the reaction mixture indicated the starting material was consumed. The solvent was removed under reduced pressure, and the residue was dissolved in EtOAc $(30 \mathrm{~mL})$ and washed with water $(2 \times 10 \mathrm{~mL})$. The combined aqueous layers were saturated with $\mathrm{NaCl}$ and extracted with 9:1 DCM:MeOH ( 5 x $10 \mathrm{~mL})$. The combined organics were dried over magnesium sulfate, filtered, and concentrated. The crude oil was purified by flash chromatography $\left(10 \mathrm{~g} \mathrm{SiO}_{2}, 0-10 \%\right.$ $\mathrm{MeOH} / \mathrm{DCM}$ ) to yield amide 22 as a pale yellow oil (147 mg, $67 \%) . \mathrm{R}_{\mathrm{f}}=0.50$ (9:1 DCM:MeOH); ${ }^{1} \mathrm{H}$ NMR $(300 \mathrm{MHz}$, $\left.\mathrm{CDCl}_{3}\right) \delta 7.99(\mathrm{~d}, J=7.4 \mathrm{~Hz}, 2 \mathrm{H}), 7.61-7.57(\mathrm{~m}, 1 \mathrm{H}) 7.50-7.45$ $(\mathrm{m}, 2 \mathrm{H}), 3.96(\mathrm{~s}, 2 \mathrm{H}), 3.48(\mathrm{q}, J=5.5 \mathrm{~Hz}, 2 \mathrm{H}), 2.79-2.73(\mathrm{~m}$, $6 \mathrm{H}), 1.14(\mathrm{t}, J=7.1 \mathrm{~Hz}, 6 \mathrm{H}) ;{ }^{13} \mathrm{C}$ NMR $\left(300 \mathrm{MHz}, \mathrm{CDCl}_{3}\right) \delta$ 
195.16, 178.19, 136.43, 133.82, 128.84, 128.70, 51.54, 47.03, $46.53,36.49,10.50 ;$ LC-MS $_{\mathrm{R}}=1.06 ; \mathrm{m} / \mathrm{z}=263.15(\mathrm{M}+\mathrm{H})$.

2-(2-Oxo-1,2-dihydropyridin-1-yl)acetic acid (25). Ester $21(3.59 \mathrm{~g}, 19.8 \mathrm{mmol})$ and $\mathrm{EtOH}: \mathrm{H}_{2} \mathrm{O}(1: 1,60 \mathrm{~mL})$ were added to a $250 \mathrm{~mL}$ oven-dried flask with stir bar and cooled to $0{ }^{\circ} \mathrm{C}$. A $1 \mathrm{~N}$ aqueous solution of $\mathrm{LiOH}(40 \mathrm{~mL}, 40 \mathrm{mmol})$ was added and the solution was stirred for $2 \mathrm{~h}$ at $20^{\circ} \mathrm{C}$. After $2 \mathrm{~h}$, ethanol was removed under vacuum and $2 \mathrm{M} \mathrm{HCl}$ was added to the aqueous solution to reach a $\mathrm{pH} \sim 6$. Next, the solution was concentrated down to dryness and the crude solid was dissolved with DCM and purified via flash chromatography (50 $\mathrm{g} \mathrm{SiO}_{2}$, $0-10 \% \mathrm{MeOH} / \mathrm{DCM}$ w/ $0.1 \%$ formic acid) to afford 25 as a white powder $(2.04 \mathrm{~g}, 67 \%)$. This compound has been previously reported and characterized (CAS\# 56546-36-2). ${ }^{29}{ }^{1} \mathrm{H}$ NMR (400 MHz, acetone- $\left.d_{6}\right) \delta$ 7.62-7.60 (m, 1H), 7.46-7.42 (m, 1H), 6.41-6.25 (m, 1H), 6.26-6.21 (m, 1H), $4.71(\mathrm{~s}, 2 \mathrm{H})$.

[2-(Diethylamino)ethyl][(4-methoxyphenyl)me-

thyl]amine (26b). $N, N$-diethylethylenediamine $(1.25 \mathrm{~g}, 10.6$ $\mathrm{mmol}$ ) was added to a $100 \mathrm{~mL}$ oven-dried flask with stir bar and sealed under $\mathrm{N}_{2}$. $i$-PrOH $(25 \mathrm{~mL})$ was added and the flask was cooled to $0^{\circ} \mathrm{C}$. Then, $p$-anisaldehyde $(1.58 \mathrm{~mL}, 12.8 \mathrm{mmol})$ was added dropwise, and the reaction was slowly warmed to $20^{\circ} \mathrm{C}$ and stirred for $16 \mathrm{~h}$. $\mathrm{MeOH}(20 \mathrm{~mL})$ was added, the solution was cooled to $0{ }^{\circ} \mathrm{C}$, and $\mathrm{NaBH}_{4}(1.69 \mathrm{~g}, 44.7 \mathrm{mmol})$ was added in portions over $1 \mathrm{~h}$. The solution was stirred for an additional $1 \mathrm{~h}$, while warmed to $20^{\circ} \mathrm{C}$. A solution of $10 \% \mathrm{NaOH}$ in $\mathrm{H}_{2} \mathrm{O}$ $(25 \mathrm{~mL})$ was added and the resulting mixture was extracted with DCM (3 x $40 \mathrm{~mL})$. The combined organic layers were washed with a $10 \%$ aqueous solution of $\mathrm{NaI}(50 \mathrm{~mL})$. The organic layers were dried over $\mathrm{Na}_{2} \mathrm{SO}_{4}$, filtered, and concentrated. The resulting crude yellow oil was dissolved in DCM $(5 \mathrm{~mL})$ and ether $(10 \mathrm{~mL})$, cooled to $0{ }^{\circ} \mathrm{C}$, and a $4 \mathrm{M} \mathrm{HCl}$ solution in 1,4-dioxane $(5.6 \mathrm{~mL}, 22.4 \mathrm{mmol})$ was added dropwise. The white precipitate was filtered and washed with DCM and diethyl ether to yield an off-white solid. This was dissolved in water $(30 \mathrm{~mL})$, cooled to $0{ }^{\circ} \mathrm{C}$, and the solution was basified with $\mathrm{NaOH}$ (to $\mathrm{pH} \sim 9$ ). The resulting mixture was extracted with DCM $(3 \times 40 \mathrm{~mL})$. The combined organics were dried over $\mathrm{Na}_{2} \mathrm{SO}_{4}$, filtered, and concentrated to yield amine 26b as a yellow oil (1.86 g, 74\% yield). This compound has been previously reported (CAS\# 65875-40-3). $\mathrm{R}_{\mathrm{f}}=0.57$ (9:1 DCM:MeOH); ${ }^{1} \mathrm{H} \mathrm{NMR} \mathrm{(300} \mathrm{MHz,}$ $\left.\mathrm{CDCl}_{3}\right) \delta 7.23(\mathrm{~d}, J=8.6 \mathrm{~Hz}, 2 \mathrm{H}), 6.85(\mathrm{~d}, J=8.6 \mathrm{~Hz}, 2 \mathrm{H}), 3.79$ $(\mathrm{s}, 3 \mathrm{H}), 3.74(\mathrm{~s}, 2 \mathrm{H}), 2.66(\mathrm{t}, J=6.2 \mathrm{~Hz}, 2 \mathrm{H}), 2.55(\mathrm{t}, J=6.2$ $\mathrm{Hz}, 2 \mathrm{H}), 2.49$ (q, $J=7.1 \mathrm{~Hz}, 4 \mathrm{H}), 0.99(\mathrm{t}, 6 \mathrm{H}) ;{ }^{13} \mathrm{C}$ NMR $(75$ $\left.\mathrm{MHz}, \mathrm{CDCl}_{3}\right) \delta 158.56,132.83,129.31,113.75,55.31,53.53$, 52.71, 47.08, 46.93, 11.93; LC-MS $\mathrm{t}_{\mathrm{R}}=0.89 ; \mathrm{m} / \mathrm{z}=236.90$ $(\mathrm{M}+\mathrm{H})$.

$\mathrm{N}$-[2-(Diethylamino)ethyl]-2-(2-oxo-1,2-dihydropyridin1-yl)acetamide (27a). Carboxylic acid $25(37.0 \mathrm{mg}, 0.242$ mmol) was added to an oven-dried $50 \mathrm{~mL}$ flask with stir bar and sealed under $\mathrm{N}_{2}$. To the suspension, anhydrous DCM $(4.0 \mathrm{~mL})$, HOBt (69.4 mg, $0.363 \mathrm{mmol})$, DIPEA (62.0 uL, $0.362 \mathrm{mmol})$, and $N, N$-diethyethylenediamine $(33.7 \mathrm{mg}, 0.290 \mathrm{mmol})$ were sequentially added. The reaction mixture was stirred for $5 \mathrm{~min}$ at $20^{\circ} \mathrm{C}$ before $\mathrm{EDC}-\mathrm{HCl}(69.4 \mathrm{mg}, 0.362 \mathrm{mmol})$ was added in one portion. The reaction mixture was stirred at $20{ }^{\circ} \mathrm{C}$ for $48 \mathrm{~h}$. Monitoring via LC-MS showed conversion to the desired product. The solvent was removed under vacuum and the residue was dry loaded using Celite and purified via flash chromatography $\left(12 \mathrm{~g} \mathrm{C} 18,0-95 \% \mathrm{MeOH} / \mathrm{H}_{2} \mathrm{O}\right.$ gradient w/ $\left.0.1 \% \mathrm{NH}_{4} \mathrm{OH}\right)$ to yield amide $27 \mathbf{a}$ as a pale yellow oil $(21 \mathrm{mg}, 35 \%) .{ }^{1} \mathrm{H}$ NMR $\left(300 \mathrm{MHz}, \mathrm{CDCl}_{3}\right) \delta 7.38-7.38(\mathrm{~m}, 2 \mathrm{H}), 6.61(\mathrm{~d}, J=9.0 \mathrm{~Hz}$, $1 \mathrm{H}), 6.24(\mathrm{td}, J=1.3,6.7 \mathrm{~Hz}, 1 \mathrm{H}), 4.56(\mathrm{~s}, 2 \mathrm{H}), 3.30$ (q, $J=5.7$ $\mathrm{Hz}, 2 \mathrm{H}), 2.57-2.50(\mathrm{~m}, 7 \mathrm{H}), 0.99(\mathrm{t}, J=7.1 \mathrm{~Hz}, 6 \mathrm{H}) ;{ }^{13} \mathrm{C} \mathrm{NMR}$
(75 MHz, $\left.\mathrm{CD}_{3} \mathrm{OD}\right) \delta 168.1,163.6,141.5,139.8,139.7,119.3$, $107.2,52.0,51.2,46.9,36.6,10.3 ; \mathrm{LC}-\mathrm{MS} \mathrm{t} \mathrm{t}_{\mathrm{R}}=0.99 ; \mathrm{m} / \mathrm{z}=$ $251.80(\mathrm{M}+\mathrm{H})$.

$\mathrm{N}$-[2-(Diethylamino)ethyl]-N-[(4-methoxyphenyl)methyl]-2-(2-oxo-1,2-dihydropyridin-1-yl)acetamide (27b). Carboxylic acid $25(0.300 \mathrm{~g}, 19.6 \mathrm{mmol})$ was added to an oven dried $50 \mathrm{~mL}$ flask with stir bar and sealed under $\mathrm{N}_{2}$. Anhydrous DCE $(20.0 \mathrm{~mL})$ was added, and the resulting mixture was cooled to $0{ }^{\circ} \mathrm{C}$ using an ice bath before $\mathrm{EDC}-\mathrm{HCl}(0.563,29.4$ mmol), amine 27b (0.300 g, $19.6 \mathrm{mmol})$, and DMAP (23.9 mg, $1.96 \mathrm{mmol}$ ) were added. The reaction was allowed to warm up to $20{ }^{\circ} \mathrm{C}$ and stirred under $\mathrm{N}_{2}$ for $16 \mathrm{~h}$. The resulting solution was washed with $1 \mathrm{M} \mathrm{NaOH}(10 \mathrm{~mL})$. The aqueous layer was extracted with DCM $(2 \times 5 \mathrm{~mL})$, and the combined organic layers were dried over anhydrous $\mathrm{Na}_{2} \mathrm{SO}_{4}$, filtered, and concentrated. The crude yellow oil was dissolved with DCM and purified via flash chromatography $\left(12 \mathrm{~g} \mathrm{C} 18,0-95 \% \mathrm{MeOH} / \mathrm{H}_{2} \mathrm{O}\right.$ with $\left.0.1 \% \mathrm{NH}_{4} \mathrm{OH}\right)$ to yield amide $27 \mathbf{b}$ as a colorless oil $(213$ $\mathrm{mg}, 29 \%)$. The ${ }^{1} \mathrm{H}$ and ${ }^{13} \mathrm{C} \mathrm{NMR}$ are complicated due to rotamers. ${ }^{1} \mathrm{H}$ NMR $\left(300 \mathrm{MHz}, \mathrm{CDCl}_{3}\right) \delta$ 7.39-7.24 (m, 3H), 7.20 $7.18(\mathrm{~m}, 1 \mathrm{H}), 6.93-6.91(\mathrm{~m}, 1 \mathrm{H}), 6.85-6.82(\mathrm{~m}, 1 \mathrm{H}), 6.58-6.54$ $(\mathrm{m}-1 \mathrm{H}), 6.22-6.16(\mathrm{~m}, 1 \mathrm{H}), 4.89(\mathrm{~s}, 1 \mathrm{H}), 4.73(\mathrm{~s}, 1 \mathrm{H}), 4.66(\mathrm{~s}$, $1 \mathrm{H}), 4.59$ (s, 1H), 3.80-3.77 (s, 3H), 3.46-3.37 (m, 2H), 2.64 $2.45(\mathrm{~m}, 6 \mathrm{H}), 1.03-0.95(\mathrm{~m}, 6 \mathrm{H}) ;{ }^{13} \mathrm{C}$ NMR $\left(75 \mathrm{MHz}, \mathrm{CDCl}_{3}\right)$ $\delta 167.0,166.7,162.5,162.4,159.2,159.0,140.0,140.0,138.9$, $138.7,129.5,129.1,128.2,127.9,120.4,114.3,114.0,105.8$, $105.7,55.3,55.2,51.5,51.3,50.3,49.7,49.4,48.9,47.5,47.4$, 45.6, 45.3, 45.2, 12.0; LC-MS $t_{R}=1.43 ; \mathrm{m} / \mathrm{z}=371.95(\mathrm{M}+\mathrm{H})$.

Benzyl 2-bromo-3-hydroxy-3-phenylpropanoate (35a). To a $25 \mathrm{~mL}$ flask with stir bar, benzyl cinnamate $(477 \mathrm{mg}, 2.00$ mmol), NBS (427 mg, $2.40 \mathrm{mmol}$ ) and $\mathrm{MeCN}: \mathrm{H}_{2} \mathrm{O}(4: 1)(10$ $\mathrm{mL}$ ) were added and the solution was cooled to $0{ }^{\circ} \mathrm{C}$. Iodine $(50.8 \mathrm{mg}, 0.200 \mathrm{mmol})$ was added and the mixture was stirred for $72 \mathrm{~h}$. The reaction mixture was washed with $10 \%$ aq. sodium thiosulfate $(20 \mathrm{~mL})$ and extracted with EtOAc $(3 \times 40$ $\mathrm{mL})$. The combined organic extracts were washed with brine, dried over anhydrous $\mathrm{Na}_{2} \mathrm{SO}_{4}$, filtered, and concentrated. The crude product was dissolved in DCM and purified by flash chromatography ( $50 \mathrm{~g} \mathrm{SiO}_{2}, 0-100 \%$ EtOAc/hexanes) to afford bromohydrin 35a as a colorless liquid (276 mg, 41\%). This compound has been previously reported (CAS\# 1332928-50-3). $\mathrm{R}_{\mathrm{f}}=0.47$ (50:50 EtOAc:hexanes); ${ }^{1} \mathrm{H} \mathrm{NMR}\left(300 \mathrm{MHz}, \mathrm{CDCl}_{3}\right)$ $\delta$ 7.23-7.37 (m, 10H), $5.20(\mathrm{~s}, 2 \mathrm{H}), 5.07(\mathrm{dd}, J=5.5,8.2 \mathrm{~Hz}$, $1 \mathrm{H}), 4.41(\mathrm{~d}, J=8.2 \mathrm{~Hz}, 1 \mathrm{H}), 3.26(\mathrm{br} \mathrm{d}, J=5.5 \mathrm{~Hz}, 1 \mathrm{H}) ;{ }^{13} \mathrm{C}$ NMR $\left(75 \mathrm{MHz}, \mathrm{CDCl}_{3}\right) \delta 169.3,139.0,134.9,128.9,128.7$, $128.7,128.3,127.0,75.3,68.0,47.8$

Methyl 2-bromo-3-hydroxy-3-phenylpropanoate (35b). The procedure for the synthesis of bromohydrin 35a was used with the following modifications: methyl trans-cinnamate (1.62 $\mathrm{g}, 10.0 \mathrm{mmol})$ was used instead of benzyl trans-cinnamate, NBS (2.14 g, $12.0 \mathrm{mmol}), \mathrm{MeCN}: \mathrm{H}_{2} \mathrm{O}(4: 1)(50 \mathrm{~mL})$, and iodine $(254 \mathrm{mg}, 1.00 \mathrm{mmol})$. The crude product was dissolved in DCM and purified by flash chromatography (100 $\mathrm{g} \mathrm{SiO}_{2}, 0$ $40 \%$ EtOAc/hexanes) to afford bromohydrin $\mathbf{3 5 b}$ as an offwhite solid (1.45 g, 56\%). This compound has been previously reported (CAS\# 90841-69-3). ${ }^{30} \quad \mathrm{R}_{\mathrm{f}}=0.38$ (70:30 hexanes:EtOAc); ${ }^{1} \mathrm{H}$ NMR $\left(300 \mathrm{MHz}, \mathrm{CDCl}_{3}\right) \delta 7.35-7.38(\mathrm{~m}$, $5 \mathrm{H}), 5.06(\mathrm{dd}, J=5.3,8.4 \mathrm{~Hz}, 1 \mathrm{H}), 4.37$ (d, $J=8.4 \mathrm{~Hz}, 1 \mathrm{H})$, $3.79(\mathrm{~s}, 3 \mathrm{H}), 3.28(\mathrm{~d}, J=5.3 \mathrm{~Hz}, 1 \mathrm{H}) ;{ }^{13} \mathrm{C} \mathrm{NMR}(75 \mathrm{MHz}$, $\left.\mathrm{CDCl}_{3}\right) \delta 170.0,139.0,128.9,128.7,127.1,75.3,53.3,47.5$.

Benzyl 3-phenyloxirane-2-carboxylate (36). In a $4 \mathrm{~mL}$ oven-dried vial with stir bar, a suspension of 2-hydroxypryidone $(6.8 \mathrm{mg}, 0.072 \mathrm{mmol})$, tetrabutylammonium bromide (1.9 $\mathrm{mg}, 0.0060 \mathrm{mmol})$, and ground potassium carbonate $(24.7 \mathrm{mg}$, 
$0.179 \mathrm{mmol})$ in acetone $(0.5 \mathrm{~mL})$ was heated at $40{ }^{\circ} \mathrm{C}$ for 30 min. A solution of the bromohydrin 35a (20.0 mg, 0.0597 $\mathrm{mmol})$ in acetone $(0.2 \mathrm{~mL})$ was added dropwise over $5 \mathrm{~min}$ and the mixture was stirred at $40{ }^{\circ} \mathrm{C}$ for $30 \mathrm{~min}$. The reaction mixture was monitored via LCMS and TLC (50:50 EtOAc:hexanes) and stained with PAA. Saturated $\mathrm{NH}_{4} \mathrm{Cl}(1 \mathrm{~mL})$ and $\mathrm{H}_{2} \mathrm{O}$ $(1 \mathrm{~mL})$ were added the solution was stirred for $10 \mathrm{~min}$. The resulting solution was diluted with $\mathrm{H}_{2} \mathrm{O}(5 \mathrm{~mL})$ and extracted with DCM $(3 \times 10 \mathrm{~mL})$. The combined organic layers were dried over anhydrous $\mathrm{Na}_{2} \mathrm{SO}_{4}$, filtered, and concentrated. The crude pale yellow oil was dissolved in DCM and purified by flash chromatography (5 $\mathrm{g} \mathrm{SiO}_{2}, 0-100 \%$ EtOAc/hexanes) to yield pyridone 36 as a colorless oil (11.4 mg, 75\%). This compound has been previously reported and synthesized (CAS\# 14466757-2). ${ }^{1} \mathrm{H}$ NMR $\left(300 \mathrm{MHz}, \mathrm{CDCl}_{3}\right) \delta 3.55(\mathrm{~d}, J=1.7 \mathrm{~Hz}, 1 \mathrm{H})$, $4.11(\mathrm{~d}, J=1.7 \mathrm{~Hz}, 1 \mathrm{H}), 5.25(\mathrm{~m}, 2 \mathrm{H}), 7.25-7.40(\mathrm{~m}, 10 \mathrm{H}) ;{ }^{13} \mathrm{C}$ NMR $\left(75 \mathrm{MHz}, \mathrm{CDCl}_{3}\right) \delta 168.2,135.1,135.0,129.2,128.8$, $128.8,128.7,126.0,67.6,58.2,56.9$.

Methyl 2-bromo-3-[(tert-butyldimethylsilyl)oxy]-3-phenylpropanoate (37a). Bromohydrin 35a $(70.0 \mathrm{mg}, 0.209 \mathrm{mg})$ was added to a $4 \mathrm{~mL}$ oven-dried vial with stir bar and sealed under $\mathrm{N}_{2}$. Anhydrous DCM $(1.0 \mathrm{~mL})$, 2.6-lutidine $(92.0 \mathrm{uL}$, $0.794 \mathrm{mmol})$ and TBSOTf $(72.0 \mathrm{uL}, 0.314 \mathrm{mmol})$ were sequentially added and the solution was stirred at $20^{\circ} \mathrm{C}$ for $2 \mathrm{~h}$. TLC analysis (50:50 EtOAc:hexanes) indicated consumption of starting material. The reaction was quenched with the slow addition of saturated $\mathrm{NaCl}(2 \mathrm{~mL})$, and the mixture was stirred for $15 \mathrm{~min}$. The aqueous layer was extracted with ether $(2 \times 10 \mathrm{~mL})$, and the organic layer was washed with brine $(5 \mathrm{~mL})$, dried over anhydrous $\mathrm{Na}_{2} \mathrm{SO}_{4}$, filtered, and condensed. The crude yellow oil was dissolved in DCM and purified by flash chromatography (25 $\mathrm{g} \mathrm{SiO}_{2}, 0-20 \% \mathrm{EtOAc} /$ hexanes) to yield $37 \mathbf{a}$ as a pale yellow oil ( $277 \mathrm{mg}, 77 \%)$. This compound has been previously reported and synthesized (CAS\# 175722-72-2). $\mathrm{R}_{\mathrm{f}}=0.68$ (70:30 hexanes:EtOAc); ${ }^{1} \mathrm{H}$ NMR $\left(300 \mathrm{MHz}, \mathrm{CDCl}_{3}\right) \delta 7.31-$ $7.38(\mathrm{~m}, 5 \mathrm{H}), 4.98(\mathrm{~d}, J=9.8 \mathrm{~Hz}, 1 \mathrm{H}), 4.21(\mathrm{~d}, J=9.8 \mathrm{~Hz}, 1 \mathrm{H})$, $3.81(\mathrm{~s}, 3 \mathrm{H}), 0.79(\mathrm{~s}, 9 \mathrm{H}), 0.01(\mathrm{~s}, 3 \mathrm{H}),-0.29(\mathrm{~s}, 3 \mathrm{H}) ;{ }^{13} \mathrm{C} \mathrm{NMR}$ $\left(75 \mathrm{MHz}, \mathrm{CDCl}_{3}\right) \delta 169.6,140.1,128.7,127.7,76.7,53.0,49.4$, $25.6,18.0,-4.7,-3.3$.

Methyl 2-bromo-3-(methoxymethoxy)-3-phenylpropanoate (37b). Bromohydrin 35a (100 mg, $0.386 \mathrm{mmol})$ was added to a $4 \mathrm{~mL}$ oven-dried vial with stir bar and sealed under $\mathrm{N}_{2}$. Anhydrous DCM $(1.0 \mathrm{~mL})$ was added and the solution was cooled to $0{ }^{\circ} \mathrm{C}$. Then, 2,6 -lutidine $(67.4 \mathrm{uL}, 0.579 \mathrm{mmol})$ was added followed by dropwise addition of methoxychloromethane $(44 \mathrm{uL}, 0.579 \mathrm{mmol})$. The solution was stirred at $0{ }^{\circ} \mathrm{C}$ for $1 \mathrm{~h}$ and allowed to warm up to room temperature, then stirred at room temperature for $16 \mathrm{~h}$ under $\mathrm{N}_{2}$. After $16 \mathrm{~h}$, the reaction was diluted with EtOAc $(15 \mathrm{~mL})$ and washed with saturated aq. $\mathrm{NaHCO}_{3}(10 \mathrm{~mL})$. The aqueous layer was extracted with EtOAc $(2 \times 10 \mathrm{~mL})$, and the combined organic layers were dried over anhydrous $\mathrm{Na}_{2} \mathrm{SO}_{4}$, filtered, and concentrated. The crude yellow oil was dissolved in DCM and purified by flash chromatography (5 $\mathrm{g} \mathrm{SiO}_{2}, 0-40 \%$ EtOAc/hexanes) to yield $37 \mathrm{~b}$ as a colorless oil $(78 \mathrm{mg}, 66 \%) . \mathrm{R}_{\mathrm{f}}=0.59(70: 30$ hexanes:EtOAc); ${ }^{1} \mathrm{H}$ NMR $\left(300 \mathrm{MHz}, \mathrm{CDCl}_{3}\right) \delta 7.40-7.35(\mathrm{~m}$, $5 \mathrm{H}), 5.00(\mathrm{~d}, J=10.1 \mathrm{~Hz}, 1 \mathrm{H}), 4.54-4.45(\mathrm{~m}, 2 \mathrm{H}), 4.33(\mathrm{~d}, J=$ $10.1 \mathrm{~Hz}, 1 \mathrm{H}), 3.85$ (s, 3H), 3.25 (s, 3H); ${ }^{13} \mathrm{C} \mathrm{NMR}(75 \mathrm{MHz}$, $\left.\mathrm{CDCl}_{3}\right) \delta 169.4,136.9,129.1,128.7,128.6,128.4,128.4$, 127.1, 94.8, 78.7, 56.1, 53.1, 47.3.

Methyl 3-(acetyloxy)-2-bromo-3-phenylpropanoate (39). Bromohydrin 35b (3.28 g, $12.6 \mathrm{mmol})$ was added to a $50 \mathrm{~mL}$ oven-dried flask with stir bar and sealed under $\mathrm{N}_{2}$. Anhydrous DCM $(20.0 \mathrm{~mL})$, acetic anhydride $(1.34 \mathrm{~mL}, 14.3 \mathrm{mmol})$ and
DMAP (61.8 mg, $0.506 \mathrm{mmol})$ were sequentially added. The solution was stirred at $20^{\circ} \mathrm{C}$ for $16 \mathrm{~h}$. TLC analysis (50:50 hexanes:EtOAc) confirmed consumption of starting material. The reaction mixture was poured into ice cold $\mathrm{H}_{2} \mathrm{O}(100 \mathrm{~mL})$, and extracted with DCM (3 x $100 \mathrm{~mL})$. The combined organic layers were washed with brine $(100 \mathrm{~mL})$, dried over anhydrous $\mathrm{Na}_{2} \mathrm{SO}_{4}$, filtered, and concentrated. The crude pale yellow oil was dissolved in DCM and purified by flash chromatography (100 $\mathrm{g} \mathrm{SiO}_{2}, 0-20 \% \mathrm{EtOAc/hexanes)} \mathrm{to} \mathrm{yield} 39$ as a colorless oil (3.55 g, 93\%). This compound has been previously reported and synthesized (CAS\# 59339-56-9). $\quad \mathrm{R}_{\mathrm{f}}=0.73 \quad(50: 50$ EtOAc:hexanes); ${ }^{1} \mathrm{H}$ NMR $\left(300 \mathrm{MHz}, \mathrm{CDCl}_{3}\right) \delta 7.43-7.35(\mathrm{~m}$, $5 \mathrm{H}), 6.11(\mathrm{~d}, J=9.9 \mathrm{~Hz}, 1 \mathrm{H}), 4.50(\mathrm{~d}, J=9.9 \mathrm{~Hz}, 1 \mathrm{H}), 3.81(\mathrm{~s}$, $3 \mathrm{H}), 2.02(\mathrm{~s}, 3 \mathrm{H}) ;{ }^{13} \mathrm{C}$ NMR $\left(75 \mathrm{MHz}, \mathrm{CDCl}_{3}\right) \delta 168.8,168.3$, 136.0, 129.3, 128.6, 128.0, 75.6, 53.3, 46.1, 20.9.

Methyl 2-(acetyloxy)-3-(2-oxo-1,2-dihydropyridin-1-yl)3-phenylpropanoate (40b). 2-Hydroxypyridine (3.55 g, 37.4 $\mathrm{mmol})$ and $\mathrm{Cs}_{2} \mathrm{CO}_{3}(8.11 \mathrm{~g}, 24.9 \mathrm{mmol})$ were added to a 250 $\mathrm{mL}$ oven-dried flask with stir bar and sealed under $\mathrm{N}_{2}$. Anhydrous DMF $(75 \mathrm{~mL})$ was added and the suspension was heated at $50{ }^{\circ} \mathrm{C}$ for $1 \mathrm{~h}$, then cooled to $20^{\circ} \mathrm{C}$. A solution of alkyl bromide 39 ( $7.50 \mathrm{~g}, 24.9 \mathrm{mmol})$ in anhydrous DMF $(20 \mathrm{~mL})$ was added and the reaction mixture was stirred at $20{ }^{\circ} \mathrm{C}$ for $16 \mathrm{~h}$. The reaction was quenched with saturated aq. $\mathrm{NH}_{4} \mathrm{Cl}(75 \mathrm{~mL})$, diluted with EtOAc $(500 \mathrm{~mL})$, and washed with $\mathrm{H}_{2} \mathrm{O}(6 \times 200$ $\mathrm{mL})$. The organic layer was dried over anhydrous $\mathrm{Na}_{2} \mathrm{SO}_{4}$, filtered, and concentrated. The resulting crude yellow oil was dissolved in DCM and purified by flash chromatography (100 g $\mathrm{SiO}_{2}, 0-100 \% \mathrm{EtOAc} /$ hexanes) to yield $40 \mathrm{~b}$ as a waxy offwhite solid (1.98 g, 25\%) and 41b as an off-white solid (0.60 g, 9\%). 40b: ${ }^{1} \mathrm{H}$ NMR $\left(400 \mathrm{MHz}, \mathrm{CDCl}_{3}\right) \delta$ 7.49-7.47 (m, 2H), $7.39-7.38(\mathrm{~m}, 3 \mathrm{H}), 7.27-7.25(\mathrm{~m}, 1 \mathrm{H}), 7.05(\mathrm{~d}, J=7.1 \mathrm{~Hz}, 1 \mathrm{H})$, $6.87(\mathrm{~d}, J=5.1 \mathrm{~Hz}, 1 \mathrm{H}), 6.60(\mathrm{~d}, J=9.7 \mathrm{~Hz}, 1 \mathrm{H}), 6.02(\mathrm{t}, J=$ $6.7 \mathrm{~Hz}, 1 \mathrm{H}), 5.89(\mathrm{~d}, J=7.1 \mathrm{~Hz}, 1 \mathrm{H}), 3.65(\mathrm{~s}, 3 \mathrm{H}), 2.14(\mathrm{~s}, 3 \mathrm{H})$ $;{ }^{13} \mathrm{C}$ NMR $\left(100 \mathrm{MHz}, \mathrm{CDCl}_{3}\right) \delta 169.4,167.9,162.2,139.4$, 135.9, 134.6, 129.5, 129.3, 129.1, 120.7, 105.8, 71.3, 57.2, 53.0, 20.7; LC-MS $t_{\mathrm{R}}=5.50 ; \mathrm{m} / \mathrm{z}=255.75(\mathrm{M}+\mathrm{H}) .41 \mathrm{~b}:{ }^{1} \mathrm{H}$ NMR $\left(400 \mathrm{MHz}, \mathrm{CDCl}_{3}\right) \delta 7.50-7.37(\mathrm{~m}, 7 \mathrm{H}), 7.12(\mathrm{ddd}, J=6.8,2.1$, $0.7 \mathrm{~Hz}, 1 \mathrm{H}), 6.68-6.65(\mathrm{~m}, 1 \mathrm{H}), 6.65(\mathrm{~s}, 1 \mathrm{H}), 6.28(\mathrm{td}, J=6.8$, $1.2 \mathrm{~Hz}, 1 \mathrm{H}), 3.69(\mathrm{~s}, 3 \mathrm{H}) ;{ }^{13} \mathrm{C} \mathrm{NMR}\left(100 \mathrm{MHz}, \mathrm{CDCl}_{3}\right) \delta 164.0$, $161.8,151.1,140.6,137.5,131.2,129.5,129.2,126.6,122.1$, 115.8, 105.9, 52.0; LC-MS $t_{R}=4.25 ; \mathrm{m} / \mathrm{z}=255.75(\mathrm{M}+\mathrm{H})$.

2-Hydroxy-3-(2-oxo-1,2-dihydropyridin-1-yl)-3-phenylpropanoic acid (42b). To a $50 \mathrm{~mL}$ flask with stir bar, acetate $40 \mathrm{~b}(1.98 \mathrm{~g}, 6.28 \mathrm{mmol})$, THF (48 mL), $\mathrm{H}_{2} \mathrm{O}(12 \mathrm{~mL})$, and $\mathrm{LiOH}-\mathrm{H}_{2} \mathrm{O}(580 \mathrm{mg}, 13.8 \mathrm{mmol})$ were sequentially added and the reaction was stirred at $20{ }^{\circ} \mathrm{C}$ for $30 \mathrm{~min}$. Analysis via LCMS indicated complete conversion. THF was removed under vacuum before a $1 \mathrm{M} \mathrm{HCl}$ solution was added dropwise until the $\mathrm{pH}$ reached $\sim 1$. The solution was concentrated, the crude product was dry loaded using Celite, and purified via flash chromatography $\left(12 \mathrm{~g} \mathrm{C} 18,0-95 \% 0.5 \mathrm{~N} \mathrm{NH}_{3}\right.$ in $\left.\mathrm{MeOH} / \mathrm{H}_{2} \mathrm{O}\right)$ to afford carboxylic acid 42b as an off-white solid (1.49 g, 92\%). ${ }^{1} \mathrm{H}$ NMR (400 MHz, DMSO-d6) $\delta$ 7.49-7.47 (m, 3H), 7.37-7.29 $(\mathrm{m}, 4 \mathrm{H}), 6.43-6.40(\mathrm{~m}, 2 \mathrm{H}), 6.15(\mathrm{t}, J=6.7 \mathrm{~Hz}, 1 \mathrm{H}), 4.66(\mathrm{~d}, J$ $=5.0 \mathrm{~Hz}, 1 \mathrm{H}) \cdot{ }^{13} \mathrm{C}$ NMR $(100 \mathrm{MHz}, \mathrm{DMSO}-d 6) \delta 173.2,161.2$, 139.7, 137.6, 136.8, 129.3, 128.6, 128.1, 119.2, 105.0, 70.4, 58.2; LC-MS t $\mathrm{t}_{\mathrm{R}}=3.34 ; \mathrm{m} / \mathrm{z}=258.05(\mathrm{M}-\mathrm{H})$.

(2-Aminoethoxy)(tert-butyl)dimethylsilane (44). Ethanolamine $(2.07 \mathrm{~g}, 33.9 \mathrm{mmol})$ was added to a $25 \mathrm{~mL}$ oven-dried flask with stir bar and sealed under $\mathrm{N}_{2}$. Imidazole (4.61 g, 67.8 $\mathrm{mmol})$ and anhydrous DCM $(30 \mathrm{~mL})$ were added before a solution of TBSCl $(5.11 \mathrm{~g}, 33.9 \mathrm{mmol})$ in anhydrous DCM $(5 \mathrm{~mL})$ was added dropwise over $10 \mathrm{~min}$ via syringe pump at $20^{\circ} \mathrm{C}$. 
The solution was allowed to stir at room temperature for $1 \mathrm{~h}$. Next, the solution was diluted with DCM $(150 \mathrm{~mL})$ and washed with water $(3 \times 50 \mathrm{~mL})$ and brine $(50 \mathrm{~mL})$. The organic layer was dried over $\mathrm{MgSO}_{4}$, filtered, and concentrated to give amine 44 as a pale yellow oil ( $4.77 \mathrm{~g}, 80 \%)$. This compound has been previously reported and synthesized (CAS\# 101711-55-1). ${ }^{1} \mathrm{H}$ $\mathrm{NMR}\left(\mathrm{CDCl}_{3}, 400 \mathrm{MHz}\right) \delta 3.63(\mathrm{t}, J=5.2 \mathrm{~Hz}, 2 \mathrm{H}), 2.77(\mathrm{t}, J=$ $5.2 \mathrm{~Hz}, 2 \mathrm{H}), 1.47$, (br s, 2H), $0.91(\mathrm{~s}, 9 \mathrm{H}), 0.07(\mathrm{~s}, 6 \mathrm{H}) ;{ }^{13} \mathrm{C}$ NMR $\left(\mathrm{CDCl}_{3}, 100 \mathrm{MHz}\right) \delta 65.5,44.5,26.1,18.5,-5.2$.

$\mathrm{N}$-\{2-[(Tert-butyldimethylsilyl)oxy]ethyl\}-2-hydroxy-3-(2oxo-1,2-dihydropyridin-1-yl)-3-phenylpropanamide (46). To an oven-dried $50 \mathrm{~mL}$ round bottom flask, acid $42(420 \mathrm{mg}, 1.62$ $\mathrm{mmol}$ ), amine 44 (568 mg, 3.24), anhydrous DMF (10 mL), and anhydrous DCE $(10 \mathrm{~mL})$ were added. Next, NMM (356 uL, $3.24 \mathrm{mmol}$ ) was added via syringe and HATU (739 mg, 1.94 mmol) was added in one portion. The reaction mixture was stirred at $20^{\circ} \mathrm{C}$ for $16 \mathrm{~h}$ under $\mathrm{N}_{2}$. After $16 \mathrm{~h}$, the reaction mixture was diluted with EtOAc $(200 \mathrm{~mL})$ and washed with $\mathrm{H}_{2} \mathrm{O}(2$ $\mathrm{x} 50 \mathrm{~mL})$ and brine $(50 \mathrm{~mL})$. The organic layer was dried over anhydrous $\mathrm{Na}_{2} \mathrm{SO}_{4}$, filtered, and condensed under vacuum to yield a crude yellow oil. The crude oil was purified by flash chromatography (25 g SiO $2,0-100 \%$ EtOAc/hexanes) to afford amide 46 as a colorless oil $(620 \mathrm{mg}, 91 \%) .{ }^{1} \mathrm{H} \mathrm{NMR}(400 \mathrm{MHz}$, $\left.\mathrm{CDCl}_{3}\right) \delta 7.44-7.40(\mathrm{~m}, 1 \mathrm{H}), 7.35-7.30(\mathrm{~m}, 7 \mathrm{H}), 6.81(\mathrm{br} \mathrm{s}$, $1 \mathrm{H}), 6.68(\mathrm{~d}, J=9.1 \mathrm{~Hz}, 1 \mathrm{H}), 6.25(\mathrm{t}, J=7.3 \mathrm{~Hz}, 1 \mathrm{H}), 6.00(\mathrm{~s}$, $1 \mathrm{H}), 4.84(\mathrm{~s}, 1 \mathrm{H}), 3.66-3.53(\mathrm{~m}, 2 \mathrm{H}), 3.42-3.30(\mathrm{~m}, 2 \mathrm{H}), 0.87$ $(\mathrm{s}, 9 \mathrm{H}), 0.02(\mathrm{~s}, 6 \mathrm{H}) ;{ }^{13} \mathrm{C} \mathrm{NMR}\left(100 \mathrm{MHz}, \mathrm{CDCl}_{3}\right) \delta 170.9$, $164.9,140.6,139.2,135.0,128.7,128.6,128.4,121.6,107.7$, $74.5,61.8,41.6,31.6,26.0,18.4,-5.3 ; \mathrm{LC}-\mathrm{MS} \mathrm{t}_{\mathrm{R}}=5.74 ; \mathrm{m} / \mathrm{z}=$ $417.00(\mathrm{M}+\mathrm{H})$

$N$-\{2-[(Tert-butyldimethylsilyl)oxy]ethyl\}-2-oxo-3-(2oxo-1,2-dihydropyridin-1-yl)-3-phenylpropanamide (47). Alcohol 46 (205 mg, $0.492 \mathrm{mmol}$ ) was added to a $20 \mathrm{~mL}$ ovendried vial with stir bar and sealed under $\mathrm{N}_{2}$. Anhydrous DCM $(10 \mathrm{~mL})$ and DMP (251 mg, $0.592 \mathrm{mmol})$ were added and the reaction was stirred at $20^{\circ} \mathrm{C}$ for $2 \mathrm{~h}$ under $\mathrm{N}_{2}$. A $10 \% \mathrm{Na}_{2} \mathrm{~S}_{2} \mathrm{O}_{3}$ aqueous solution $(10 \mathrm{~mL})$ was added and the biphasic mixture was stirred for $20 \mathrm{~min}$ until the two layers became clear. The aqueous layer was separated and the organic layer was washed with saturated $\mathrm{NaHCO}_{3}(2 \times 5 \mathrm{~mL})$. The combined aqueous layers were extracted with EtOAc $(1 \times 10 \mathrm{~mL})$ and the combined organics were dried over anhydrous $\mathrm{Na}_{2} \mathrm{SO}_{4}$, filtered, and concentrated. The crude oil was dissolved in DCM and purified via flash chromatography (25 $\mathrm{g} \mathrm{SiO}_{2}, 0-80 \%$ EtOAc/hexanes) to afford ketone 47 as an off-white solid (170 mg, 83\%). ${ }^{1} \mathrm{H}$ NMR $\left(400 \mathrm{MHz}, \mathrm{CDCl}_{3}\right) \delta 7.38-7.26(\mathrm{~m}, 7 \mathrm{H}), 6.93(\mathrm{~d}, J=7.0 \mathrm{~Hz}$, $1 \mathrm{H}), 6.85(\mathrm{~s}, 1 \mathrm{H}), 6.52(\mathrm{~d}, J=9.1 \mathrm{~Hz}, 1 \mathrm{H}), 6.08(\mathrm{t}, J=6.7 \mathrm{~Hz}$, 1H), 3.64-3.60 (m, 2H), 3.43-3.25 (m, 2H), $0.80(\mathrm{~s}, 9 \mathrm{H}),-0.04$ $(\mathrm{s}, 6 \mathrm{H}) ;{ }^{13} \mathrm{C} \mathrm{NMR}\left(100 \mathrm{MHz}, \mathrm{CDCl}_{3}\right) \delta 189.76,162.43,159.43$, $140.19,135.48,130.69,130.21,129.95,129.71,119.70$, $106.46,64.34,61.33,41.51,25.87,18.24,-5.35 ;$ LC-MS $t_{R}=$ $6.09 ; \mathrm{m} / \mathrm{z}=414.95(\mathrm{M}+\mathrm{H})$.

$\mathrm{N}$-(2-Hydroxyethyl)-2-oxo-3-(2-oxo-1,2-dihydropyridin1-yl)-3-phenylpropanamide (48). To a $100 \mathrm{~mL}$ flask charged with a stir bar, silyl ether 47 (100 mg, $0.241 \mathrm{mmol}$ ) and $\mathrm{MeOH}$ $(10.0 \mathrm{~mL})$ were added. Then a $2 \%$ aqueous $\mathrm{HCl}$ in $\mathrm{MeOH}$ solution $(10.0 \mathrm{~mL})$ was added, and the reaction was stirred for 1 $\mathrm{h}$ at $20^{\circ} \mathrm{C}$. The solution was concentrated, dry loaded on to Celite, and purified via flash chromatography (12 g C18, 0 $\left.40 \% \mathrm{MeOH} / \mathrm{H}_{2} \mathrm{O}\right)$ to afford alcohol 48 as a colorless oil $(56.7$ $\mathrm{mg}, 78 \%)$. LC-MS $\mathrm{t}_{\mathrm{R}}=3.64 ; \mathrm{m} / \mathrm{z}=300.85(\mathrm{M}+\mathrm{H})$. This intermediate was used directly in the next step.

Diethyl(\{2-[2-oxo-3-(2-oxo-1,2-dihydropyridin-1-yl)-3phenylpropanamido]ethyl $\}$ )azanium chloride (50). Alcohol
48 (40.0 mg, $0.133 \mathrm{mmol}$ ) was added to a $20 \mathrm{~mL}$ oven-dried vial with stir bar and sealed under Ar. Anhydrous MeCN (4.0 $\mathrm{mL}$ ), DIPEA (22.8 uL, $0.133 \mathrm{mmol}$ ), and $\mathrm{MsCl}$ (30.9 uL, 0.400 mmol) were respectively added and the solution was stirred at $20^{\circ} \mathrm{C}$ for $24 \mathrm{~h}$. Analysis via TLC confirmed conversion to the mesylate. Diethylamine $(275 \mathrm{uL}, 2.66 \mathrm{mmol})$ was added and the reaction was heated at $70{ }^{\circ} \mathrm{C}$ for $16 \mathrm{~h}$ under Ar. The reaction was concentrated, dry loaded using Celite, and purified via flash chromatography $\left(10 \mathrm{~g} \mathrm{C} 18, \mathrm{MeOH} / \mathrm{H}_{2} \mathrm{O}\right.$ gradient w/ $0.1 \%$ formic acid) to afford the free base of amine $\mathbf{5 0}$ as an off-white powder (11.0 mg, 28\%). $\mathrm{R}_{\mathrm{f}}=0.61$ (95:5 DCM:MeOH); ${ }^{1} \mathrm{H}$ $\operatorname{NMR}\left(400 \mathrm{MHz}, \mathrm{CDCl}_{3}\right) \delta 8.61(\mathrm{~s}, 1 \mathrm{H}), 8.03(\mathrm{~s}, 1 \mathrm{H}), 7.51-7.49$ (m, 3H), 7.41 (ddd, $J=8.8,6.6,1.9 \mathrm{~Hz}, 1 \mathrm{H}), 7.37-7.35(\mathrm{~m}, 2 \mathrm{H})$, $6.90(\mathrm{dd}, J=7.1,1.7 \mathrm{~Hz}, 1 \mathrm{H}), 6.55(\mathrm{~d}, J=8.8 \mathrm{~Hz}, 1 \mathrm{H}), 6.15(\mathrm{td}$, $J=6.6,1.2 \mathrm{~Hz}, 1 \mathrm{H}), 6.07(\mathrm{~s}, 1 \mathrm{H}), 4.73-4.70(\mathrm{~m}, 1 \mathrm{H}), 4.26-4.22$ $(\mathrm{m}, 1 \mathrm{H}), 3.86-3.58(\mathrm{~m}, 6 \mathrm{H}), 1.36-1.24(\mathrm{~m}, 6 \mathrm{H})$. This compound had poor solubility in chloroform and $\mathrm{MeOH}$. The $\mathrm{HCl}$ salt was formed prior to ${ }^{13} \mathrm{C}$ NMR analysis. The product was taken up into minimal $\mathrm{H}_{2} \mathrm{O}$ and $0.5 \mathrm{~mL}$ of $1 \mathrm{M} \mathrm{HCl}$ was added. The solution was lyophilized to afford a yellow oil. ${ }^{13} \mathrm{C}$ NMR $(75 \mathrm{MHz}$, $\left.\mathrm{D}_{2} \mathrm{O}\right) \delta 170.4,164.2,155.1,143.0,136.5,131.0,131.0,130.4$, $129.9,129.8,118.9,109.2,64.83,64.63,49.67,45.54,41.91$, 13.3, 10.6; LC-MS t $\mathrm{t}_{\mathrm{R}}=1.61 ; \mathrm{m} / \mathrm{z}=356.40(\mathrm{M}+\mathrm{H})$.

Ethyl 2-(2-oxo-1,2-dihydropyridin-1-yl)-3-phenylpropanoate (51). In a $20 \mathrm{~mL}$ oven-dried vial with stir bar, HMDS $(1.90 \mathrm{~mL}, 9.11 \mathrm{mmol})$ and anhydrous THF $(9.0 \mathrm{~mL})$ were added under $\mathrm{N}_{2}$. The solution was cooled to $0{ }^{\circ} \mathrm{C}$ in an ice bath before $n$-butyl lithium $(5.43 \mathrm{~mL}$ of a $1.6 \mathrm{M}$ solution in hexanes, 8.69 mmol) was added dropwise over $10 \mathrm{~min}$. The solution was cooled to $-78{ }^{\circ} \mathrm{C}$ before a solution of ester 21 (1.50 g, 8.28 $\mathrm{mmol})$ in anhydrous THF $(25.0 \mathrm{~mL})$ was added dropwise. The solution was stirred at $-78^{\circ} \mathrm{C}$ for $1 \mathrm{~h}$ under $\mathrm{N}_{2}$ before benzylbromide $(985 \mathrm{uL}, 8.28 \mathrm{mmol})$ was added dropwise. The reaction mixture was stirred at $-78{ }^{\circ} \mathrm{C}$ for $1 \mathrm{~h}$, allowed to warm up to 0 ${ }^{\circ} \mathrm{C}$, quenched with saturated $\mathrm{NH}_{4} \mathrm{Cl}(10 \mathrm{~mL})$, and diluted with EtOAc $(50 \mathrm{~mL})$. The organic layer was separated, washed with brine, dried over anhydrous $\mathrm{Na}_{2} \mathrm{SO}_{4}$, filtered, and concentrated. The crude material was dissolved in DCM and purified via flash chromatography (100 $\mathrm{g} \mathrm{SiO}_{2}, 0-40 \% \mathrm{EtOAc} /$ hexanes) to afford 51 as a colorless oil $(1.52 \mathrm{~g}, 68 \%) .{ }^{1} \mathrm{H}$ NMR $\left(300 \mathrm{MHz}, \mathrm{CDCl}_{3}\right)$ $\delta 7.28-7.18(\mathrm{~m}, 4 \mathrm{H}), 7.11-7.08(\mathrm{~m}, 2 \mathrm{H}), 7.03(\mathrm{dd}, J=6.9,1.5$ $\mathrm{Hz}, 1 \mathrm{H}), 6.50(\mathrm{~d}, J=9.2 \mathrm{~Hz}, 1 \mathrm{H}), 6.03(\mathrm{td}, J=6.8,1.3 \mathrm{~Hz}, 1 \mathrm{H})$, $5.41(\mathrm{dd}, J=9.7,5.6 \mathrm{~Hz}, 1 \mathrm{H}), 4.21(\mathrm{q}, J=7.1 \mathrm{~Hz}, 2 \mathrm{H}), 3.50(\mathrm{~m}$, $1 \mathrm{H}), 3.33(\mathrm{~m}, 1 \mathrm{H}), 1.23(\mathrm{t}, J=7.1 \mathrm{~Hz}, 3 \mathrm{H}) ;{ }^{13} \mathrm{C} \mathrm{NMR}(75 \mathrm{MHz}$, $\left.\mathrm{CDCl}_{3}\right) \delta 169.46,162.16,139.64,136.50,136.11,129.12$, $128.69,127.09,120.75,105.64,61.92,61.16,36.33,14.12$; LC$M S t_{\mathrm{R}}=4.67 ; \mathrm{m} / \mathrm{z}=271.90(\mathrm{M}+\mathrm{H})$.

Ethyl (2Z)-2-(2-oxo-1,2-dihydropyridin-1-yl)-3-phenylprop-2-enoate (53). The procedure for the synthesis of 51 was followed using HMDS (392 mg, $2.43 \mathrm{mmol}$ ), anhydrous THF $(9.0 \mathrm{~mL}), n$-butyl lithium $(1.45 \mathrm{~mL}$ of a $1.6 \mathrm{M}$ solution in hexanes, $2.32 \mathrm{mmol}), 21$ (400 $\mathrm{mg}, 2.21 \mathrm{mmol})$ in anhydrous THF $(3.0 \mathrm{~mL})$, and benzaldehyde $(0.247 \mathrm{~mL}, 2.43 \mathrm{mmol})$ instead of benzylbromide. After workup, the product was dissolved in DCM and purified via flash chromatography (25 g $\mathrm{SiO}_{2}, 0-50 \%$ EtOAc/hexanes) to afford alkene $\mathbf{5 3}$ as an offwhite solid (272 mg, 46\%). ${ }^{1} \mathrm{H}$ NMR $\left(400 \mathrm{MHz}, \mathrm{CDCl}_{3}\right) \delta 7.83$ (s, 1H), 7.43 (ddd, $J=9.0,6.6,2.0 \mathrm{~Hz}, 1 \mathrm{H}), 7.33-7.26(\mathrm{~m}, 3 \mathrm{H})$, $7.20-7.18(\mathrm{~m}, 2 \mathrm{H}), 6.96(\mathrm{dd}, J=6.7,1.8 \mathrm{~Hz}, 1 \mathrm{H}), 6.67(\mathrm{~d}, J=$ $8.7 \mathrm{~Hz}, 1 \mathrm{H}), 6.18(\mathrm{td}, J=6.7,1.0 \mathrm{~Hz}, 1 \mathrm{H}), 4.31(\mathrm{q}, J=7.1 \mathrm{~Hz}$, $2 \mathrm{H}), 1.31(\mathrm{t}, J=7.1 \mathrm{~Hz}, 3 \mathrm{H}) ;{ }^{13} \mathrm{C} \mathrm{NMR}\left(100 \mathrm{MHz}, \mathrm{CDCl}_{3}\right) \delta$ $163.4,162.4,140.8,137.7,137.4,131.4,130.5,130.2,129.9$, $128.9,121.8,106.8,62.0,14.1 . \mathrm{LC}-\mathrm{MS} \mathrm{t}_{\mathrm{R}}=6.06 ; \mathrm{m} / \mathrm{z}=269.80$ $(\mathrm{M}+\mathrm{H})$. 
(2Z)-2-(2-Oxo-1,2-dihydropyridin-1-yl)-3-phenylprop-2enoic acid (54). To a $15 \mathrm{~mL}$ flask with stir bar, ester 53 (136 $\mathrm{mg}, 0.504 \mathrm{mmol})$, THF $(6.0 \mathrm{~mL}), \mathrm{H}_{2} \mathrm{O}(1.5 \mathrm{~mL})$, and LiOH$\mathrm{H}_{2} \mathrm{O}(25.4 \mathrm{mg}, 0.604 \mathrm{mmol})$ were added and the solution was stirred at $20^{\circ} \mathrm{C}$ for $12 \mathrm{~h}$. THF was removed under vacuum before a $1 \mathrm{M} \mathrm{HCl}$ solution was added dropwise until the $\mathrm{pH}$ reached $\sim 1$. The solution was concentrated under vacuum and the crude product was dry loaded using Celite and purified via flash chromatography (12 g C18, $0-75 \% \mathrm{MeOH} / \mathrm{H}_{2} \mathrm{O}$ w/ $0.1 \%$ formic acid) to afford carboxylic acid $\mathbf{5 4}$ as an off-white solid (108 mg, 89\%). ${ }^{1} \mathrm{H}$ NMR (400 MHz, CD $\left.3 \mathrm{OD}\right) \delta 7.94(\mathrm{~s}, 1 \mathrm{H})$, 7.65 (ddd, $J=9.1,6.7,2.0 \mathrm{~Hz}, 1 \mathrm{H}), 7.39-7.30$ (m, 4H), 7.20$7.18(\mathrm{~m}, 2 \mathrm{H}), 6.67(\mathrm{~d}, J=9.1 \mathrm{~Hz}, 1 \mathrm{H}), 6.42(\mathrm{td}, J=6.7,1.0 \mathrm{~Hz}$, $1 \mathrm{H}) ;{ }^{13} \mathrm{C} \mathrm{NMR}\left(100 \mathrm{MHz}, \mathrm{CD}_{3} \mathrm{OD}\right) \delta 166.2,164.8,143.6$, 140.0, 139.0, 133.1, 131.7, 131.6, 130.9, 130.1, 121.6, 109.4; LC-MS t $=4.17 ; \mathrm{m} / \mathrm{z}=241.75(\mathrm{M}+\mathrm{H})$.

Ethyl 3-hydroxy-2-(2-oxo-1,2-dihydropyridin-1-yl)-3phenylpropanoate (55). In a $100 \mathrm{~mL}$ oven-dried flask with stir bar, diisopropylamine $(309 \mu \mathrm{L}, 2.21 \mathrm{mmol})$ and anhydrous THF $(35.0 \mathrm{~mL})$ were added via syringe under $\mathrm{N}_{2}$. The solution was cooled to $-78^{\circ} \mathrm{C}$ in a dry ice/acetone bath before $n$-butyl lithium $(1.38 \mathrm{~mL}$ of a $1.6 \mathrm{M}$ solution in hexanes, $2.21 \mathrm{mmol}$ ) was added dropwise over $10 \mathrm{~min}$. The solution was allowed to stir for 30 min before a solution of 21 (400 mg, $2.21 \mathrm{mmol})$ in anhydrous THF $(3.0 \mathrm{~mL})$ was added dropwise over $5 \mathrm{~min}$. The heterogenous solution was stirred at $-78^{\circ} \mathrm{C}$ for $1 \mathrm{~h}$ before benzaldehyde $(0.247 \mathrm{~mL}, 2.43 \mathrm{mmol})$ was added, and the solution was stirred at $-78^{\circ} \mathrm{C}$ for $2 \mathrm{~h}$. The reaction was quenched at $-78^{\circ} \mathrm{C}$ via the addition saturated aq. $\mathrm{NH}_{4} \mathrm{Cl}(15 \mathrm{~mL})$ and diluted with EtOAc $(75 \mathrm{~mL})$. The organic layer was separated, washed with brine, dried over anhydrous $\mathrm{Na}_{2} \mathrm{SO}_{4}$, filtered, and concentrated. The crude material was dissolved in DCM and purified via flash chromatography ( $50 \mathrm{~g} \mathrm{SiO}_{2}, 0-100 \%$ EtOAc/hexanes) to afford alcohol 55 as a colorless oil (307 mg, 48\%). The NMR spectra are complex due to diastereomers. ${ }^{1} \mathrm{H}$ NMR $\left(300 \mathrm{MHz}, \mathrm{CDCl}_{3}\right)$ $\delta 7.59(\mathrm{dd}, J=6.8,1.3 \mathrm{~Hz}, 1 \mathrm{H}), 7.26-7.15(\mathrm{~m}, 12 \mathrm{H}), 6.80(\mathrm{dd}$, $J=6.8,1.5 \mathrm{~Hz}, 1 \mathrm{H}), 6.39(\mathrm{~d}, J=9.1 \mathrm{~Hz}, 1 \mathrm{H}), 6.28(\mathrm{~d}, J=9.1$ $\mathrm{Hz}, 1 \mathrm{H}), 6.05$ (td, $J=6.7,1.2 \mathrm{~Hz}, 1 \mathrm{H}), 5.86(\mathrm{td}, J=6.7 \mathrm{~Hz}, 1.2$ $\mathrm{Hz}, 1 \mathrm{H}), 5.81(\mathrm{~d}, J=4.3 \mathrm{~Hz}, 1 \mathrm{H}), 5.63(\mathrm{~d}, J=4.3 \mathrm{~Hz}, 1 \mathrm{H}), 5.45$ $(\mathrm{d}, J=7.5 \mathrm{~Hz}, 1 \mathrm{H}), 4.74(\mathrm{~d}, J=7.5 \mathrm{~Hz}, 1 \mathrm{H}), 4.22-4.16(\mathrm{~m}, 4 \mathrm{H})$, $1.24-1.19(\mathrm{~m}, 6 \mathrm{H}) ;{ }^{13} \mathrm{C} \mathrm{NMR}\left(75 \mathrm{MHz}, \mathrm{CDCl}_{3}\right) \delta 169.4,168.2$, $162.9,162.3,140.2,140.1,139.5,138.9,138.5,137.9,128.4$, $128.3,127.8,126.4,125.9,120.3,119.7,105.9,105.6,73.5$, $72.1,67.5,63.5,62.1,62.1,60.4,21.1,14.2,14.1,14.0$; LC-MS $\mathrm{t}_{\mathrm{R}}=4.78,4.92 ; \mathrm{m} / \mathrm{z}=287.80(\mathrm{M}+\mathrm{H})$.

Ethyl 3-[(tert-butyldimethylsilyl)oxy]-2-(2-oxo-1,2-dihydropyridin-1-yl)-3-phenylpropanoate (56). The procedure for the synthesis of $\mathbf{3 7} \mathbf{a}$ was used with the following modifications: 55 (153 mg, $0.533 \mathrm{mmol})$, DCM $(6.0 \mathrm{~mL}), 2,6$-lutidine (74.4 uL, $0.639 \mathrm{mmol})$ and TBSOTf $(147 \mathrm{uL}, 0.639 \mathrm{mmol})$ were used. The crude oil was dissolved in DCM and purified via flash chromatography (25 $\mathrm{g} \mathrm{SiO}_{2}, 0-50 \%$ EtOAc/hexanes) to yield 56 as a pale yellow oil (187 mg, 87\%). ${ }^{1} \mathrm{H}$ NMR (300 $\left.\mathrm{MHz}, \mathrm{CDCl}_{3}\right) \delta 8.20(\mathrm{dd}, J=6.9,1.4 \mathrm{~Hz}, 1 \mathrm{H}), 7.87(\mathrm{dd}, J=6.9$, $1.4 \mathrm{~Hz}, 1 \mathrm{H}), 7.56-7.38(\mathrm{~m}, 11 \mathrm{H}), 6.62(\mathrm{~d}, J=9.2 \mathrm{~Hz}, 1 \mathrm{H}), 6.53$ $(\mathrm{d}, J=9.2 \mathrm{~Hz}, 1 \mathrm{H}), 6.44-6.39(\mathrm{~m}, 1 \mathrm{H}), 6.33-6.28(\mathrm{~m}, 1 \mathrm{H}), 6.12$ $(\mathrm{d}, J=7.2 \mathrm{~Hz}, 1 \mathrm{H}), 5.87(\mathrm{~d}, J=3.9 \mathrm{~Hz}, 1 \mathrm{H}), 5.44(\mathrm{~d}, J=7.2$ $\mathrm{Hz}, 1 \mathrm{H}), 4.59-4.51(\mathrm{~m}, 1 \mathrm{H}), 4.45-4.33(\mathrm{~m}, 3 \mathrm{H}), 1.53(\mathrm{t}, J=7.1$ $\mathrm{Hz}, 3 \mathrm{H}), 1.46(\mathrm{t}, J=7.1 \mathrm{~Hz}, 3 \mathrm{H}), 1.13(\mathrm{~s}, 9 \mathrm{H}), 1.11(\mathrm{~s}, 9 \mathrm{H}), 0.29$ $(\mathrm{s}, 3 \mathrm{H}), 0.25(\mathrm{~s}, 3 \mathrm{H}), 0.02(\mathrm{~s}, 3 \mathrm{H}), 0.00(\mathrm{~s}, 3 \mathrm{H}) .{ }^{13} \mathrm{C}$ NMR $(75$ $\left.\mathrm{MHz} \mathrm{CDCl}_{3}\right) \delta 169.0,168.5,162.2,161.8,139.6,139.5,139.4$, $139.3,138.7,136.6,128.3,128.2,128.2,128.2,127.0,126.4$, $120.4,119.7,105.4,104.5,75.6,75.4,62.1,61.9,61.7,61.5$, $25.8,25.8,18.1,18.1,14.2,14.1,-4.4,-4.6,-5.3,-5.5$; LC-MS $\mathrm{t}_{\mathrm{R}}=6.95 ; \mathrm{m} / \mathrm{z}=401.95(\mathrm{M}+\mathrm{H})$.
Prop-2-en-1-yl 2-(2-oxo-1,2-dihydropyridin-1-yl)acetate (57). $\mathrm{NaH}$ (60\% dispersion in mineral oil, $1.77 \mathrm{~g}, 46.3 \mathrm{mmol})$ was added to a $500 \mathrm{~mL}$ oven-dried flask with stir bar and sealed under $\mathrm{N}_{2}$. Anhydrous DMF (125 mL) was added and the suspension was cooled to $0{ }^{\circ} \mathrm{C}$ in an ice bath. A solution of 2-hydroxypyridine $(4.00 \mathrm{~g}, 42.1 \mathrm{mmol})$ in anhydrous DMF $(25.0$ $\mathrm{mL}$ ) was slowly added and stirred for $1 \mathrm{~h}$ at $0{ }^{\circ} \mathrm{C}$. Allyl chloroacetate $(5.98 \mathrm{~mL}, 50.5 \mathrm{mmol})$ was added and the mixture was stirred at $20^{\circ} \mathrm{C}$ for $12 \mathrm{~h}$. The reaction was quenched with saturated $\mathrm{NH}_{4} \mathrm{Cl}(200 \mathrm{~mL})$ and diluted with EtOAc $(750 \mathrm{~mL})$. The organic layer was washed with water $(6 \times 200 \mathrm{~mL})$, dried over anhydrous $\mathrm{Na}_{2} \mathrm{SO}_{4}$, filtered, and concentrated. The crude product was dissolved in DCM and purified via flash chromatography $\left(100 \mathrm{~g} \mathrm{SiO}_{2}, 0-85 \% \mathrm{EtOAc} /\right.$ hexanes) to afford pyridone 57 as a pale yellow oil $(3.40 \mathrm{~g}, 42 \%) .{ }^{1} \mathrm{H}$ NMR $(400 \mathrm{MHz}$, $\left.\mathrm{CDCl}_{3}\right) \delta 7.30(\mathrm{ddd}, J=9.2,6.7,2.1 \mathrm{~Hz}, 1 \mathrm{H}), 7.20$ (ddd, $J=$ $6.7,2.1,0.7 \mathrm{~Hz}, 1 \mathrm{H}), 6.49$ (ddd, $J=9.2,1.4,0.7 \mathrm{~Hz}, 1 \mathrm{H}), 6.13$ $(\mathrm{td}, J=6.7,1.4 \mathrm{~Hz}, 1 \mathrm{H}), 5.82(\mathrm{ddt}, J=17.2,10.5,5.7 \mathrm{~Hz}, 1 \mathrm{H})$, $5.25(\mathrm{dq}, J=17.21 .5 \mathrm{~Hz}, 1 \mathrm{H}), 5.17(\mathrm{dq}, J=10.5,1.3 \mathrm{~Hz}, 1 \mathrm{H})$, $4.60(\mathrm{~s}, 2 \mathrm{H}), 4.58(\mathrm{dt}, J=5.7,1.4 \mathrm{~Hz}, 2 \mathrm{H}) .{ }^{13} \mathrm{C} \mathrm{NMR}(100 \mathrm{MHz}$, $\left.\mathrm{CDCl}_{3}\right) \delta 167.5,162.4,140.3,138.0,131.3,121.0,119.0,106.2$, 66.3, 50.5. LC-MS t $t_{R}=2.30 ; \mathrm{m} / \mathrm{z}=181.90(\mathrm{M}+\mathrm{H})$.

Prop-2-en-1-yl 3-hydroxy-2-(2-oxo-1,2-dihydropyridin1-yl)-3-phenylpropanoate (58). In an oven-dried $100 \mathrm{~mL}$ flask with stir bar, anhydrous THF $(50.0 \mathrm{~mL})$ and diisopropylamine $(1.55 \mathrm{~mL}, 11.0 \mathrm{mmol})$ were added via syringe under $\mathrm{N}_{2}$. The solution was cooled to $-78^{\circ} \mathrm{C}$ before $n$-butyl lithium $(6.90 \mathrm{~mL}$ of a $1.6 \mathrm{M}$ solution in hexanes, $11.0 \mathrm{mmol}$ ) was added dropwise over $5 \mathrm{~min}$. The solution was stirred for $30 \mathrm{~min}$ before a solution of ester $57(1.94 \mathrm{~g}, 10.0 \mathrm{mmol})$ in anhydrous THF $(8.0 \mathrm{~mL})$ was added dropwise over 5 min and stirred at $-78^{\circ} \mathrm{C}$ for $1 \mathrm{~h}$. Benzaldehyde $(1.53 \mathrm{~mL}, 15.1 \mathrm{mmol})$ was added and the resulting solution was stirred at $-78{ }^{\circ} \mathrm{C}$ for $2 \mathrm{~h}$. The reaction was quenched at $-78{ }^{\circ} \mathrm{C}$ with saturated aq. $\mathrm{NH}_{4} \mathrm{Cl}$ and diluted with EtOAc $(200 \mathrm{~mL})$ and $\mathrm{H}_{2} \mathrm{O}(10 \mathrm{~mL})$. The layers were separated and the organic layer was washed with brine, dried over anhydrous $\mathrm{Na}_{2} \mathrm{SO}_{4}$, and concentrated. The crude yellow oil was dissolved in DCM and purified via flash chromatography (100 g $\mathrm{SiO}_{2}, 0-70 \%$ EtOAc/hexanes) to afford alcohol $\mathbf{5 8}$ as a yellow oil $(2.45 \mathrm{~g}, 82 \%) .{ }^{1} \mathrm{H}$ NMR $\left(400 \mathrm{MHz}, \mathrm{CDCl}_{3}\right) \delta 7.43$ (d, $J=$ $7.9 \mathrm{~Hz}, 1 \mathrm{H}), 7.27-7.22(\mathrm{~m}, 13 \mathrm{H}), 6.71(\mathrm{dd}, J=6.8,1.5 \mathrm{~Hz}, 1 \mathrm{H})$, $6.46(\mathrm{~d}, J=9.1 \mathrm{~Hz}, 1 \mathrm{H}), 6.40(\mathrm{~d}, J=8.8 \mathrm{~Hz}, 1 \mathrm{H}), 6.09(\mathrm{td}, J=$ $6.8,1.3 \mathrm{~Hz}, 1 \mathrm{H}), 5.94-5.81(\mathrm{~m}, 3 \mathrm{H}), 5.73(\mathrm{~s}, 2 \mathrm{H}), 5.57(\mathrm{~d}, J=$ $7.9 \mathrm{~Hz}, 1 \mathrm{H}), 5.34-5.20(\mathrm{~m}, 4 \mathrm{H}), 4.72-4.64(\mathrm{~m}, 6 \mathrm{H}) ;{ }^{13} \mathrm{C} \mathrm{NMR}$ $\left(100 \mathrm{MHz}, \mathrm{CDCl}_{3}\right) \delta 169.2,167.9,163.1,162.4,140.3,140.2$, $139.4,138.7,138.5,137.9,131.4,131.3,128.5,128.4,128.4$, $128.0,126.4,125.9,120.5,120.0,119.1,119.0,106.0,105.8$, $73.7,72.1,68.0,66.6,66.6,64.0 ;$ LC-MS $t_{\mathrm{R}}=4.40,4.53 ; \mathrm{m} / \mathrm{z}=$ $299.75(\mathrm{M}+\mathrm{H})$.

\section{3-Hydroxy-2-(2-oxo-1,2-dihydropyridin-1-yl)-3-phe-} nylpropanoic acid (59). Alcohol $58(1.90 \mathrm{~g}, 0.264 \mathrm{mmol})$ and $\mathrm{Pd}\left(\mathrm{PPh}_{3}\right)_{4}(12.2 \mathrm{mg}, 0.0106 \mathrm{mmol})$ were added to a $500 \mathrm{~mL}$ oven-dried flash with stir bar and sealed under $\mathrm{N}_{2}$. Anhydrous THF $(6.0 \mathrm{~mL})$ and morpholine $(24.2 \mathrm{uL}, 0.277 \mathrm{mmol})$ were added via syringe and the reaction was stirred at $20{ }^{\circ} \mathrm{C}$ for 30 min. After $30 \mathrm{~min}$, analysis via LC-MS indicated consumption of starting material. The reaction mixture was concentrated, dry loaded using Celite, and purified using flash chromatography (30 g C18, 0-95\% MeOH/ $\mathrm{H}_{2} \mathrm{O}$ w/ $0.1 \%$ formic acid) to afford carboxylic acid 59 as a yellow oil $(1.20 \mathrm{~g}, 73 \%)$. ${ }^{1} \mathrm{H}$ NMR (400 $\left.\mathrm{MHz}, \mathrm{CD}_{3} \mathrm{OD}\right) \delta 8.10(\mathrm{~d}, J=6.5 \mathrm{~Hz}, 1 \mathrm{H}), 7.44(\mathrm{~d}, J=6.5 \mathrm{~Hz}$, $1 \mathrm{H}), 7.36-7.15(\mathrm{~m}, 10 \mathrm{H}), 6.37(\mathrm{~d}, J=9.0 \mathrm{~Hz}, 1 \mathrm{H}), 6.30-6.27$ $(\mathrm{m}, 1 \mathrm{H}), 6.14-6.10(\mathrm{~m}, 1 \mathrm{H}), 5.73(\mathrm{~d}, J=3.8 \mathrm{~Hz}, 1 \mathrm{H}), 5.45(\mathrm{~d}, J$ $=7.9 \mathrm{~Hz}, 1 \mathrm{H}), 5.30(\mathrm{~d}, J=7.9 \mathrm{~Hz}, 1 \mathrm{H}) . \mathrm{LC}-\mathrm{MS} \mathrm{t}_{\mathrm{R}}=3.74,3.88$; $\mathrm{m} / \mathrm{z}=259.75(\mathrm{M}+\mathrm{H})$. 
$N$-[2-(Diethylamino)ethyl]-3-hydroxy-2-(2-oxo-1,2-dihydropyridin-1-yl)-3-phenylpropanamide (60). Carboxylic acid 59 ( $886 \mathrm{mg}, 3.42 \mathrm{mmol}$ ) was added to a $500 \mathrm{~mL}$ oven-dried flask with stir bar and sealed under $\mathrm{N}_{2}$. Anhydrous DCM (150 $\mathrm{mL}$ ), HATU (1.95 g, $5.13 \mathrm{mmol})$, DIPEA (655 uL, $3.76 \mathrm{mmol}$ ), and $\underline{N}, N$-diethyethylenediamine ( $624 \mathrm{uL}, 4.44 \mathrm{mmol})$ were sequentially added and the solution was stirred at $20^{\circ} \mathrm{C}$ for $12 \mathrm{~h}$. After $12 \mathrm{~h}$, the reaction was concentrated under vacuum, dry loaded using Celite, and purified via flash chromatography (30 g C18, $0-95 \% \mathrm{MeOH} / \mathrm{H}_{2} \mathrm{O}$ w/ $0.1 \%$ formic acid) to afford amide 60 as an off-white waxy solid (918 mg, 75\%). ${ }^{1} \mathrm{H}$ NMR (400 $\left.\mathrm{MHz}, \mathrm{CD}_{3} \mathrm{OD}\right) \delta 7.44$ (dd, $\left.J=6.9,1.5 \mathrm{~Hz}, 1 \mathrm{H}\right), 7.34$ (ddd, $J=$ 9.0, 6.7, 2.0 Hz, 1H), 7.28-7.26 (m, 2H), 7.24-7.19 (m, 3H), $6.36(\mathrm{dd}, \mathrm{J}=9.0,0.6 \mathrm{~Hz}, 1 \mathrm{H}), 6.14(\mathrm{td}, J=6.7,1.3 \mathrm{~Hz}, 1 \mathrm{H})$, $5.39(\mathrm{~d}, J=9.5 \mathrm{~Hz}, 1 \mathrm{H}), 5.19(\mathrm{~d}, J=9.5 \mathrm{~Hz}, 1 \mathrm{H}), 3.79-3.73(\mathrm{~m}$, $1 \mathrm{H}), 3.64-3.57(\mathrm{~m}, 1 \mathrm{H}), 3.38-3.22(\mathrm{~m}, 6 \mathrm{H}), 1.31(\mathrm{t}, J=7.3 \mathrm{~Hz}$, $6 \mathrm{H}) ;{ }^{13} \mathrm{C}$ NMR $\left(100 \mathrm{MHz}, \mathrm{CD}_{3} \mathrm{OD}\right) \delta 171.8,164.4,142.5$, 141.1, 140.0, 129.5, 129.4, 128.0, 120.5, 108.4, 73.4, 67.3, 53.0, 49.1, 35.7, 9.2. LC-MS $\mathrm{t}_{\mathrm{R}}=1.07,1.32 ; \mathrm{m} / \mathrm{z}=357.95(\mathrm{M}+\mathrm{H})$.

$\mathrm{N}$-[2-(Diethylamino)ethyl]-3-oxo-2-(2-oxo-1,2-dihydropyridin-1-yl)-3-phenylpropanamide (61). Alcohol 60 (47.5 $\mathrm{mg}, 0.133 \mathrm{mmol}$ ) was added to a $20 \mathrm{~mL}$ oven-dried vial with stir bar and sealed under $\mathrm{N}_{2}$. Anhydrous DCM $(6.0 \mathrm{~mL})$ and DMP $(84.5 \mathrm{mg}, 0.199 \mathrm{mmol})$ were sequentially added and the reaction mixture was stirred at $20^{\circ} \mathrm{C}$ for $1 \mathrm{~h}$. After $1 \mathrm{~h}, \mathrm{H}_{2} \mathrm{O}(2.7$ $\mathrm{uL}, 0.15 \mathrm{mmol}$ ) was added via microsyringe. The reaction solution was stirred at room temperature for $48 \mathrm{~h}$ before being quenched with saturated $\mathrm{Na}_{2} \mathrm{~S}_{2} \mathrm{O}_{3}(3 \mathrm{~mL})$. The product was extracted with DCM $(3 \times 10 \mathrm{~mL})$ and concentrated. The crude product was dissolved in DCM and purified via flash chromatography (12 g SiO $2,0-20 \% \mathrm{MeOH} / \mathrm{DCM}$ ) to afford ketone $\mathbf{6 1}$ as an off-white solid $(11.7 \mathrm{mg}, 25 \%) . \mathrm{R}_{\mathrm{f}}=0.71(80: 20$ DCM:MeOH). ${ }^{1} \mathrm{H}$ NMR $\left(400 \mathrm{MHz}, \mathrm{CDCl}_{3}\right) \delta 8.01(\mathrm{~d}, J=7.1$ $\mathrm{Hz}, 2 \mathrm{H}), 7.65$ (dd, $J=6.8,1.7 \mathrm{~Hz}, 1 \mathrm{H}), 7.60-7.56(\mathrm{~m}, 1 \mathrm{H})$, $7.48-7.44(\mathrm{~m}, 1 \mathrm{H}), 7.40-7.34(\mathrm{~m}, 2 \mathrm{H}), 6.60(\mathrm{~d}, J=9.2 \mathrm{~Hz}, 1 \mathrm{H})$, $6.24(\mathrm{td}, J=6.8,1.3 \mathrm{~Hz}, 1 \mathrm{H}), 3.39-3.28(\mathrm{~m}, 2 \mathrm{H}), 2.57-2.48(\mathrm{~m}$, $6 \mathrm{H}), 0.96(\mathrm{t}, J=7.2 \mathrm{~Hz}, 6 \mathrm{H}) ;{ }^{13} \mathrm{C}$ NMR $\left(100 \mathrm{MHz}, \mathrm{CDCl}_{3}\right) \delta$ 192.0, 165.2, 162.0, 140.7, 137.4, 135.0, 134.3, 129.1, 128.8, $119.9,106.2,61.6,51.1,46.7,37.4,11.5 ;$ LC-MS $t_{R}=1.57 ; \mathrm{m} / \mathrm{z}$ $=356.20(\mathrm{M}+\mathrm{H})$.

\section{Crystallographic Data}

CCDC 2004020 and 2004021 (Scheme 10), 2004022 (Scheme 13), and 2004023 (Figure 3) contain the supplementary crystallographic data for this paper. This data can be obtained free of charge from the Cambridge Crystallographic Data Centre via https://www.ccdc.cam.ac.uk.

\section{ASSOCIATED CONTENT}

\section{Supporting Information}

${ }^{1} \mathrm{H}$ and ${ }^{13} \mathrm{C}$ NMR spectra; Additional X-ray crystallography figures and discussion.

\section{AUTHOR INFORMATION}

\section{Corresponding Author}

* Email: christopher.dockendorff@mu.edu Tel: 1-414-288-1617 ORCID

Chris Dockendorff: 0000-0002-4092-5636

\section{Author Contributions}

Proposed synthetic routes: C.D., E.G. Synthesized and characterized compounds: E.G. Determined X-ray crystal structures: S.V.L. Wrote and edited the manuscript: E.G., C.D.

\section{Funding Sources}

We thank the Foundation for Women's Wellness for supporting this project in part. E.G. thanks Arthur J. Schmitt and Marquette University for a graduate fellowship.

\section{ACKNOWLEDGMENTS}

We thank Prof. Robert Flaumenhaft and colleagues (Beth Israel Deaconess Medical Center) for testing the PDI activity of compounds in this paper. We also thank Dr. Sheng Cai for assistance with LC-MS, GC-MS, and NMR instruments, and ChemAxon Ltd. for access to chemical property and structure prediction software.

\section{REFERENCES}

1. Hatahet, F.; Ruddock, L. W., Protein Disulfide Isomerase: A Critical Evaluation of Its Function in Disulfide Bond Formation. Antioxid. Redox Signal. 2009, 11 (11), 2807-2850.

2. Xu, S.; Sankar, S.; Neamati, N., Protein Disulfide Isomerase: A Promising Target for Cancer Therapy. Drug Discov. Today 2014, 19 (3), 222-240.

3. Flaumenhaft, R., Advances in Vascular Thiol Isomerase Function. Curr. Opin. Hematol. 2017, 24 (5).

4. Cho, J.; Furie, B. C.; Coughlin, S. R.; Furie, B., A Critical Role for Extracellular Protein Disulfide Isomerase During Thrombus Formation in Mice. J. Clin. Investig. 2008, 118 (3), 1123-1131.

5. Reinhardt, C.; von Brühl, M.-L.; Manukyan, D.; Grahl, L.; Lorenz, M.; Altmann, B.; Dlugai, S.; Hess, S.; Konrad, I.; Orschiedt, L.; Mackman, N.; Ruddock, L.; Massberg, S.; Engelmann, B., Protein Disulfide Isomerase Acts as an Injury Response Signal that Enhances Fibrin Generation via Tissue Factor Activation. J. Clin. Investig. 2008, 118 (3), 1110-1122.

6. Jasuja, R.; Passam, F. H.; Kennedy, D. R.; Kim, S. H.; van Hessem, L.; Lin, L.; Bowley, S. R.; Joshi, S. S.; Dilks, J. R.; Furie, B.; Furie, B. C.; Flaumenhaft, R., Protein Disulfide Isomerase Inhibitors Constitute a New Class of Antithrombotic Agents. J. Clin. Investig. 2012, 122 (6), 2104-2113

7. Kim, K.; Hahm, E.; Li, J.; Holbrook, L.-M.; Sasikumar, P.; Stanley, R. G.; Ushio-Fukai, M.; Gibbins, J. M.; Cho, J., Platelet Protein Disulfide Isomerase is Required for Thrombus Formation but not for Hemostasis in Mice. Blood 2013, 122 (6), 1052-1061.

8. Bekendam, R. H.; Bendapudi, P. K.; Lin, L.; Nag, P. P.; Pu, J.; Kennedy, D. R.; Feldenzer, A.; Chiu, J.; Cook, K. M.; Furie, B.; Huang, M.; Hogg, P. J.; Flaumenhaft, R., A Substrate-driven Allosteric Switch that Enhances PDI Catalytic Activity. Nat. Commun. 2016, 7, 12579.

9. Zwicker, J. I.; Schlechter, B. L.; Stopa, J. D.; Liebman, H. A.; Aggarwal, A.; Puligandla, M.; Caughey, T.; Bauer, K. A.; Kuemmerle, N.; Wong, E.; Wun, T.; McLaughlin, M.; Hidalgo, M.; Neuberg, D.; Furie, B.; Flaumenhaft, R., Targeting Protein Disulfide Isomerase with the Flavonoid Isoquercetin to Improve Hypercoagulability in Advanced Cancer. JCI Insight 2019, 4 (4).

10. Khodier, C.; VerPlank, L.; Nag, P. P.; Pu, J.; Wurst, J.; Pilyugina, T.; Dockendorff, C.; Galinski, C. N.; Scalise, A. A.; Passam, F.; Hessem, L. v.; Dilks, J.; Kennedy, D. R.; Flaumenhaft, R.; Palmer, M. A. J.; Dandapani, S.; Munoz, B.; Schrieber., S. L. Identification of ML359 as a Small Molecule Inhibitor of Protein Disulfide Isomerase. https://www.ncbi.nlm.nih.gov/books/NBK189925/.

11. Claisen, L.; Meyer, K., Ueber das Amid der Acetessigsäure. Ber. Dtsch. Chem. Ges. 1902, 35 (1), 583-584.

12. Sørensen, U. S.; Falch, E.; Krogsgaard-Larsen, P., A Novel Route to 5-Substituted 3-Isoxazolols. Cyclization of N,O-DiBoc $\beta$-Keto Hydroxamic Acids Synthesized via Acyl Meldrum's Acids. J. Org. Chem. 2000, 65 (4), 1003-1007.

13. Witzeman, J. S.; Nottingham, W. D., Transacetoacetylation with tert-butyl acetoacetate: synthetic applications. J. Org. Chem. 1991, 56 (5), 1713-1718.

14. Kim, H. O.; Olsen, R. K.; Choi, O. S., Copper(I)-promoted Condensation of alpha.-amino Acids with .beta.-keto Thio Esters: Synthesis of N-acylated L-leucine Derivatives Containing (S)-4Hydroxy-5-methyl- and (S)-4-Hydroxy-2,5-dimethyl-3-oxohexanoic acid. J. Org. Chem. 1987, 52 (20), 4531-4536. 
15. Hoffmann, R. V.; Huizenga, D. J., A Simple Synthesis of 2,3Diketo Amides from 3-Keto Amides. J. Org. Chem. 1991, 56 (22), 6435-6439.

16. García, M. J.; Rebolledo, F.; Gotor, V., Lipase-catalyzed Aminolysis and Ammonolysis of $\beta$-Ketoesters. Synthesis of Optically Active $\beta$-Ketoamides. Tetrahedron 1994, 50 (23), 6935-6940.

17. Kumar, P.; Pandey, R. K., A Facile and Selective Procedure for Transesterification of $\beta$-Keto Esters Promoted by Yttria-Zirconia Based Lewis Acid Catalyst. Synlett 2000, (2), 251-253.

18. Vandavasi, J. K.; Hsiao, C.-T.; Hu, W.-P.; Boominathan, S. S. K.; Wang, J.-J., Silver(I)-Catalyzed Tandem Approach to $\beta$-Oxo Amides. Eur. J. Org. Chem. 2015, 2015 (14), 3171-3177.

19. Gramain, J. C.; Remuson, R.; Vallee, D., Intramolecular Photoreduction of .alpha.-keto Esters. Total Synthesis of (.+-.)Isoretronecanol. J. Org. Chem. 1985, 50 (5), 710-712.

20. Kuzma, P. C.; Brown, L. E.; Harris, T. M., Generation of the Dianion of N-(Trimethylsilyl)acetamide and Reaction of the Dianion with Electrophilic Reagents. J. Org. Chem. 1984, 49 (11), 2015-2018. 21. Chen, L.; Dovalsantos, E.; Yu, J.; O'Neill-Slawecki, S.; Mitchell, M.; Sakata, S.; Borer, B., A Simple Preparation of a (Pyridonyl1)propargylacetic Acid Derivative. Org. Process Res. Dev. 2006, 10 (4), 838-840.

22. Nicolaou, K. C.; Estrada, A. A.; Zak, M.; Lee, S. H.; Safina, B. S., A Mild and Selective Method for the Hydrolysis of Esters with Trimethyltin Hydroxide. Angew. Chem. Int. Ed. 2005, 44 (9), 13781382 .

23. Goodreid, J. D.; Duspara, P. A.; Bosch, C.; Batey, R. A., Amidation Reactions from the Direct Coupling of Metal Carboxylate Salts with Amines. J. Org. Chem. 2014, 79 (3), 943-954.

24. Tirpak, R. E.; Olsen, R. S.; Rathke, M. W., Carboxylation of Ketones using Triethylamine and Magnesium Halides. J. Org. Chem. 1985, 50 (24), 4877-4879.

25. Li, H.; He, Z.; Guo, X.; Li, W.; Zhao, X.; Li, Z., Iron-Catalyzed Selective Oxidation of N-Methyl Amines: Highly Efficient Synthesis of Methylene-Bridged bis-1,3-Dicarbonyl Compounds. Org. Lett. 2009, 11 (18), 4176-4179.

26. Pericas, À.; Shafir, A.; Vallribera, A., Zinc(II) Oxide: An Efficient Catalyst for Selective Transesterification of $\beta$-Ketoesters. Tetrahedron 2008, 64 (39), 9258-9263.

27. Meshram, H. M.; Reddy, P. N.; Sadashiv, K.; Yadav, J. S., Amberlyst-15®-Promoted Efficient 2-Halogenation of 1,3-Keto-esters and Cyclic Ketones using N-Halosuccinimides. Tetrahedron Lett. 2005, 46 (4), 623-626.

28. Štefane, B.; Polanc, S., A New Regio- and Chemoselective Approach to $\beta$-Keto Amides and $\beta$-Enamino Carboxamides via 1,3,2Dioxaborinanes. Synlett (04).

29. Micale, N.; Ettari, R.; Lavecchia, A.; Di Giovanni, C.; Scarbaci, K.; Troiano, V.; Grasso, S.; Novellino, E.; Schirmeister, T.; Zappalà, M., Development of Peptidomimetic Boronates as Proteasome Inhibitors. Eur. J. Med. Chem. 2013, 64, 23-34.

30. Lodh, R. S.; Borah, A. J.; Phukan, P., Synthesis of Bromohydrins using NBS in Presence of Iodine as Catalyst. Indian J. Chem. 2014, $53 B, 1425-1429$.

31. Mercadante, M. A.; Kelly, C. B.; Bobbitt, J. M.; Tilley, L. J.; Leadbeater, N. E., Synthesis of 4-Acetamido-2,2,6,6tetramethylpiperidine-1-oxoammonium Tetrafluoroborate and 4Acetamido-(2,2,6,6-tetramethyl-piperidin-1-yl)oxyl and their use in Oxidative Reactions. Nat. Protoc. 2013, 8 (4), 666-676.

32. Prévost, C., Sur un Complexe Iodo-argento-benzoïque et son Application à l'oxydation des Combinaisons éthyléniques en $\alpha$ Glycols. Comptes rendus. 1933, 196, 1129-1131.

33. Woodward, R. B.; Brutcher, F. V., cis-Hydroxylation of a Synthetic Steroid Intermediate with Iodine, Silver Acetate and Wet Acetic Acid. J. Am. Chem. 1958, 80 (1), 209-211.

34. Easton, C. J.; Hutton, C. A.; Eng, W. T.; Tiekink, E. R. T., Synthesis of Homochiral Hydroxy- $\alpha$-amino Acid Derivatives. Tetrahedron Lett. 1990, 31 (48), 7059-7062.

35. Suyama, T. L.; Gerwick, W. H.; McPhail, K. L., Survey of Marine Natural Product Structure Revisions: A Synergy of Spectroscopy and Chemical Synthesis. Bioorg. Med. Chem. 2011, 19 (22), 6675-6701.

36. Jacob, N. T.; Lockner, J. W.; Kravchenko, V. V.; Janda, K. D., Pharmacophore Reassignment for Induction of the Immunosurveillance Cytokine TRAIL. Angew. Chem. Int. Ed. 2014, 53 (26), 6628-6631.

37. Feng, B.; Li, Y.; Li, H.; Zhang, X.; Xie, H.; Cao, H.; Yu, L.; Xu, Q., Specific N-Alkylation of Hydroxypyridines Achieved by a Catalyst- and Base-Free Reaction with Organohalides. The Journal of Organic Chemistry 2018, 83 (12), 6769-6775.

38. Howard, J. L.; Sagatov, Y.; Browne, D. L., Mechanochemical Electrophilic Fluorination of Liquid Beta-ketoesters. Tetrahedron 2018, 74 (25), 3118-3123. 